\title{
The Montanus \& Neuber catalogue of 1560: prices, losses, and a new polyphonic music edition from 1556
}

Royston Gustavson

\section{Introduction}

The importance of early catalogues to music bibliography, especially in identifying lost editions, has long been known. ${ }^{1}$ Well-known examples of such studies include Albert Göhler's study of booksellers' catalogues for the Frankfurt and Leipzig book fairs, Catherine Chapman's study of the catalogue of the book collector Ferdinand Columbus, and Lawrence Bernstein's study of music in Conrad Gesner's Pandectae. ${ }^{2}$ Of the many types of catalogues, printers' catalogues are particularly valuable, since they permit analysis of many salient data, for example, how long books remained in print, or which kinds of books were less likely to be collected. Christian Coppens, who is working on a census of publishers' and booksellers' catalogues up to 1600, has written that there survive about eighty such editions published in Germany. ${ }^{3}$ There has been comparatively little study of these catalogues in the musicological literature, with notable exceptions including Konrad Ameln's study of the Gerlach catalogue and my own study of the Egenolff catalogue. ${ }^{4}$ I am currently undertaking a study of music editions in printers' catalogues. Of the many catalogues I have seen to date, by far the most interesting - besides those of Gerlach and Egenolff - is that by the Nuremberg firm led by Johann vom Berg (Montanus) and Ulrich Neuber. The firm of Montanus \& Neuber was one of the major, if not indeed the major, German music printing house of the mid-sixteenth century. Their catalogue is unusual in that, like that of Gerlach, it has a section explicitly devoted to music, and even more unusual in that it specifies for each item either printed prices or the number of printed sheets in each copy of the edition. The present study of the catalogue, in addition to providing further information on known editions, identifies a number of lost editions and includes a description of an extant anthology of polyphonic music from 1556 that has not previously been noted in the literature.

\section{The catalogue in the historical literature}

The Montanus \& Neuber catalogue does not appear in the VD16 or the USTC. The first reference to it in the literature occurs in Johann Ernesti's Die Wol-eingerichtete Buchdruckerey (1733). Ernesti, who saw an exemplar of the catalogue, ${ }^{5}$ transcribed the Latin part of the title (only) and reproduced the book titles and prices of the folio volumes in Latin (fol. $2^{r}$ ), and all but the last two of the folio volumes in German (fol. $\left.2^{r-v}\right) \cdot{ }^{6}$ Most subsequent discussion of this catalogue, including that in the musicological literature until 2018, has been based on Ernesti, and has stated that the catalogue is no longer extant. ${ }^{7}$ The next independent reference to the catalogue was in 1793, in Georg Andreas Will's Bibliotheca Norica 
Williana, in which he transcribed both the Latin and the German text on the title page. ${ }^{8} \mathrm{Al}-$ though Will's exemplar of the catalogue was bequeathed, along with the rest of his library, to the Stadtbibliothek Nürnberg, it was missing by $1888 .{ }^{9}$

Günter Richter's 1974 catalogue of sixteenth- and seventeenth-century booksellers' catalogues identified an extant exemplar in the Staatsbibliothek Bamberg, and gave a bibliographical description including title, signatures, collation, brief (four-line) description, four items of literature (not including Will) and the holding library. ${ }^{10}$ Importantly, given his deep knowledge of publishers' catalogues, Richter noted that '[t]his index is particularly noteworthy as an early example of a catalogue from the German-speaking area containing prices and information about the size of books' ${ }^{11}$ Richter also noted that an exact dating, which he does not attempt to give, would require an examination of its content. The next reference to the catalogue as extant, in 2002, is in a list of catalogues of Nuremberg publishers and booksellers by Renate Jürgensen. Jürgensen transcribes the title and lists exemplars in Nuremberg (which is not noted as missing) and Bamberg; her entry appears to be based on Richter and on the Bibliotheca Norica Williana. ${ }^{12}$

Although my 2004 entry on 'Montanus \& Neuber' in the print edition of MGG2 did not include a list of music editions and noted that the catalogue was lost, my revised 2018 entry for MGG Online included a new work-list that drew in part on the Bamberg exemplar of this catalogue. ${ }^{13}$

\section{Bibliographical description}

Title: I N D E X || LIBRORVM PER || IOANNEM MONTANVM, ET || Vlricum Neuberum, im- || preflorum. || || [Gothic] Regifter der Bü||cher / So bey Johan̄ vom || Berg/ vnd Vlrich Newber/Ge=||druckt vnd Verkaufft || werden. ||

Colophon: [none]

Format: upright octavo ${ }^{14}$

Collation and blank pages: single gathering of eight leaves, $1^{\mathrm{v}}$ and $8^{\mathrm{r}-\mathrm{v}}$ blank

Signatures: unsigned; leaves 2, 3, 4 and 5 numbered in the signature line in Arabic numerals

Watermarks: crown with double contoured half-arches (but no monde), with pearls, surmounted by a cloverleaf cross, chainlines c. $25 \mathrm{~mm}$ apart, split across leaves 2, 3, 6 and 7 on the upper inner margin and thus difficult to examine in detail ${ }^{15}$

Exemplars: D-BAs 22/H.1.d.5 (formerly D-BAs Gb.II.194); lost: D-Nst Will. VIII, 308 (missing by 1888)

Catalogues: not in VD16; not in USTC

The sole known extant exemplar is in the Staatsbibliothek Bamberg, shelfmark 22/H.l.d.5. It is in a new grey cardboard binding, with the endpaper consisting only of a pastedown at the front and back, with the old and current catalogue numbers written on the front pastedown. The exemplar has been heavily trimmed, and now measures between $134 \mathrm{~mm}$ (spine) and $136.5 \mathrm{~mm}$ (fore-edge) high, and $84 \mathrm{~mm}$ wide. The presence of the signature lines suggests that nothing has been lost, despite the heavy trimming, as nothing should be printed below each signature line. Stitching holes visible in the paper on fol. 5-8 indicate that this exemplar was formerly in an earlier binding, and that when it was rebound the stitching was not made in exactly the same place. The library stamp 'Staats-Bibliothek Bamberg' occurs on fol. $1^{\mathrm{v}}$ and fol. $7^{\mathrm{v}}$. The exemplar shows early signs of use. On the verso of the title page, numbers have been written in ink: 5, 6, 8, 10, 11, 13, 14, 
$12,15,16$ and 5 . Of particular interest is the inscription on fol. $8^{\mathrm{v}}$ which reads: 'Eucharius Schö[n] | man d[ono] d[edit] [i.e. gave as a gift] NE. || 3 Februarij || 1562. ||' Schönmann was a deacon of St Jacob, Nuremberg, from 1562 to $1567 .{ }^{16}$

\section{Overview of the catalogue}

The catalogue, transcribed in full in Appendix 11.2, lists 190 book titles. For ease of reference, I have assigned each title a number that is made up of an editorial page number followed by an editorial item number, e.g. '[10.04]'. The catalogue lists multi-volume editions as a single title, but usually specifies the number of volumes; for example, 'Luther's commentary on Genesis, in four volumes' ('Quatuor Tomi Lutheri in Genesim' [1.03]). Sometimes further bibliographical information is hidden within a single entry; for example, in the 'Six volumes of the Gospels' ('Sex Tomi Evangeliorum' [12.01]), each of the six volumes consists of a set of partbooks, and so this one entry consists of a total of thirty partbooks. On the other hand, 'The evangelical citizen's handbook' ('Des Evangelischen Burgers Hand-Büchlin' [6.20]) consists of two volumes, but the catalogue does not indicate this. For the purposes of my analysis, I have counted each title only once, regardless of the number of volumes: as a single price is given for each title, this clearly implies that they were sold as a single unit.

The books are typically divided into sections by format, from folio to $32^{\mathrm{mo}}$, and within format by language (Latin, then German). The two exceptions are the section headed 'Scholasticalia' ('School Books'), interposed between the Latin and German sections for octavo as they are all in octavo format; and a separate section headed 'Musici Libri' ('Music Books') on the final page that is not further subdivided by format and language. It is very unusual for a sixteenth-century German catalogue to have a section devoted to music; the only other ones of which I am aware are those prepared by Gerlach (one catalogue that was printed and one catalogue that is in manuscript). ${ }^{17}$ The 'Musici Libri' are all editions of polyphonic music; music-theory books are listed under 'Scholasticalia', and books containing one or more hymns (Kirchenlieder) appear in the relevant sections of the catalogue according to format and language.

Each entry gives a short title, then in many cases the author, and finally either the price or the number of sheets in the book (those for [3.08], [6.02], [6.06] and [7.09] are omitted, apparently by error); the year of publication is not given. The inclusion of either a printed price or the number of sheets for each book is unexpected. Coppens writes that 'Catalogues with fixed prices seem to be meant for retail, while catalogues listing the number of sheets in the book but not prices certainly point to the wholesale market, where a large part of the trade between booksellers was carried out by barter ${ }^{\prime}{ }^{18}$ The printed prices appear to be for 'premium' editions such as Latin folios and polyphonic music, and the number of sheets for smaller formats such as school books. Perhaps this catalogue could serve both functions: in addition to those given by Coppens, where number of sheets is given the retail purchaser could be given the price per sheet to calculate the total price, and the fixed prices indicate to the wholesale market particular editions that were not available for trade on a sheet-by-sheet basis.

It is important to note that fol. $8^{\mathrm{r}-\mathrm{v}}$ is blank and so more titles could have been included on these pages without extending the catalogue to more than eight leaves of octavo (that is, a single printed sheet). There is thus no reason to believe that any available titles were omitted.

The catalogue is not dated. The presence of the manuscript date ' 3 February 1562' in the extant exemplar means that the catalogue must have been published before that date. 
I looked for Montanus \& Neuber editions in standard bibliographies, searching for the most recent edition of each title up to 1562, and noting whether or not they were included in the catalogue. For example, all known polyphonic music editions from 1555-1560 were included, but none of the three first editions from 1561 and 1562. Again, the Montanus \& Neuber edition of the Deutsche musica (1560) by Martin Agricola that was enlarged and edited by Wolfgang Figulus is included, but their only edition of Wilflingseder's Musica teutsch (1561) was not. Of the 190 titles in the catalogue, the earliest extant Montanus \& Neuber edition of six titles dates from 1561 or later, ${ }^{19}$ and so it is reasonable to assume that, for each of these titles, there were earlier lost Montanus \& Neuber editions. As such, I have assigned the catalogue a deduced date of 1560 .

\section{Analytical methodology}

To analyse the catalogue, I set up a spreadsheet as follows. This allowed for multiple ways of manipulating the data to better understand the relationships between the various components:

- Catalogue page and assigned item number for each entry

- transcription of the entry itself

- author/editor/translator (standardised spelling)

- format

- language

- price or number of sheets

- price standardised in Pfennig

- Where an extant exemplar is known:

- VD16/RISM/Claus number or, if in none of these catalogues, the holding library

- year of publication taken from extant exemplars

- number of leaves

- number of sheets (number of leaves divided by format)

- price per sheet

To identify titles and copies, I used the VD16, USTC, KVK, Claus' Melanchthon-Bibliographie and, for music, also RISM and vdm. Where an author was not given, searches for the title in several cases gave a likely author; these names are indicated in Appendix 11.2 in square brackets. Where a title has been identified as extant, the format and number of sheets have been used to confirm the identification.

The entries for the thirty-six school books ('Scholasticalia') do not specify their format. The placement of this section in the catalogue, between the Latin books in octavo and the German books in octavo, supports the supposition that all the school books were likewise in octavo, the regular format for school textbooks at this time. Indeed, of the twenty-seven titles that survive, all are indeed in octavo. Consequently, my calculations for the school books assume that all titles are in octavo. All the school books are written in Latin, except for the last edition in the list, a music-theory textbook in German.

Analysis of this list must also take typographical errors into account. For example, one edition, [2.02], stood out as an anomaly. The Catalogue stated that it was printed on 273 sheets, but both known Montanus \& Neuber editions of this book were printed on 173 sheets. It may be assumed then that 273 was a typographical error that should have read 173. Accordingly, this has been amended in Appendix 11.2. 
In some instances, the stated number of sheets matches the number of sheets in extant editions nearly but not exactly, typically with a discrepancy of 0.5 or one sheet. This particularly affects books assigned a printing date of 1559 [1.14], [2.04], [3.09], [4.03] and $[4.13]^{20}$ but not 1560 . In some of these instances, the discrepancy may be a result of irregular gatherings in the middle of a work. For example, [2.04], a folio, is expected to be of 173 sheets but is of 174; the 'extra' sheet may be from gathering ee having an extra bifolium: the edition is signed $a-z^{6} a a-d^{6} e^{8} A-Z^{6} A a-D d^{6} E e-F F^{8}$. As an example of a 'missing' half sheet, [4.15], signed a- $-\mathrm{h}^{8} \mathrm{i}^{4} \mathrm{aa}-\mathrm{cc}^{8} \mathrm{dd}^{4}$, an octavo is listed at 12.5 sheets but is actually of twelve sheets; it finishes with a four-leaf gathering which presumably accounts for the 0.5 , but gathering $i$ is also a half sheet of four leaves, and may have been counted as a full sheet in the calculation. This suggests that rather than counting the sheets, the person who compiled the catalogue perhaps used the final signature as a shortcut to calculate the number of sheets. Where the calculation differs other than in such instances, I have assumed that the edition mentioned in the catalogue is not identical to an extant edition, and include the extant edition in a footnote but not in the table itself (see Appendix 11.2).

\section{Ulrich Neuber's brother, Valentin}

Six titles in the catalogue [5.14], [5.20], [6.03], [9.01], [9.23] and [10.09] are not extant in any edition printed by Montanus \& Neuber, yet do survive in editions printed by Ulrich Neuber's brother, Valentin, who likewise had a printing workshop in Nuremberg. Each of these six titles has a format of octavo or smaller. Montanus \& Neuber is best known for high-end folio and quarto editions and polyphonic music, whereas Valentin Neuber is best known for smaller, cheap editions, and so was not a direct competitor. This raises the question of whether Montanus \& Neuber included some of Valentin Neuber's editions in their catalogue. However, this can be ruled out. The clearest evidence is that in four of the six cases, the number of sheets given in the catalogue does not precisely match the number of sheets in the extant Valentin Neuber edition, and there is no reason why this should be so; and in another other instance, the Montanus \& Neuber edition and the Valentin Neuber edition are in different formats. ${ }^{21}$ That these titles were printed by both printing houses is not surprising: they were popular titles by best-selling authors - Erasmus, Luther and Melanchthon that were not covered by a printing privilege; editions of these works were typically issued by many printers. As noted above, the Montanus \& Neuber catalogue had two blank pages at the end, and so a section listing non-competing editions by Valentin could have been included if they had so desired. The absence of such a list provides further evidence against the existence of a sales and marketing relationship between the two printing houses.

\section{Interpreting prices}

Whenever considering sixteenth-century prices, we must properly understand the currency denominations. Different cities or areas had different currency systems that may use different names for the coins and units of accounting. Even where the same name was used for currency, it may have had a different relative value: for example, the number of Pfennig in a Florin varied from region to region.

The catalogue uses four currency denominations: Florin, Ort, Batzen and Pfennig. ${ }^{22} \mathrm{I}$ have referred to books that reference Nuremberg currency to determine the relationship between these denominations. An arithmetic book by the mathematician Michael Stifel (14871567), printed in Nuremberg by Johannes Petreius in 1546, states, under the heading 'On the 
currency of Nuremberg' ('Von Nürnbergischer Müntz'), that 2 Heller = 1 Pfennig; 30 Pfennig = 1 Pfund; and 8 Pfund and 12 Pfennig [252 Pfennig] = 1 Florin or Gulden. ${ }^{23}$ Stifel then gives the abbreviation used for each denomination. Later, he notes that 1 Batzen $=16$ Pfennig. ${ }^{24}$ Stifel does not mention the 'Ort', since it was not a coin but a measure in accounting; it is defined in an arithmetic book printed by Valentin Neuber in 1549 as equivalent to a quarter of a Florin, that is, in Nuremberg currency, 63 Pfennig or approximately 4 Batzen (64 Pfennig) ${ }^{25}$

If we arrange the books by price, from lowest to highest, the order includes the series: 2 Batzen, 2.5 Batzen, 3 Batzen, 3 Batzen, 1 Ort, 1 Ort, 5 Batzen, 5 Batzen, 0.5 Florin, 0.5 Florin, 0.5 Florin, 0.5 Florin, 3 Ort, 13 Batzen, 14 Batzen. The amount 4 Batzen (64 Pfennig) is not used, but 1 Ort (63 Pfennig or $1 / 4$ of a Florin) is used instead; again, the amounts 8 Batzen and 2 Ort are not used, but 0.5 Florin is used instead. This implies that the highest denomination was used by preference.

The prices of the books are expressed in the following denominations:

- 153 by number of sheets of paper (ranging from 1.5 to 250 sheets) ${ }^{26}$

- one in Pfennig (a polyphonic music book too small to be priced in a higher denomination)

- seventeen in Batzen

- three in Ort

- twelve in Florins

- four unpriced (each is surely an error)

For books priced in Batzen, Ort or Florins, each sheet typically cost approximately 1.5 Pfennig. The only book priced in Pfennig is not extant but there is no reason to assume that this did not have a similar pricing method. This cost is approximate, as the correlation cannot be exact; for example, the cost of books priced in Florins is given in half or whole Florins, and thus in multiples of 126 Pfennig. Using a price of 1.5 Pfennig per sheet, a book consisting of 84 sheets would cost half a Florin (126 Pfennig); a book of 168 sheets would cost 1 Florin (252 Pfennig). But books priced in Florins would normally not have this exact number of sheets. We can determine the number of sheets at which the price changes from half a florin to a florin. I have developed a model (see Table 11.1) to predict this, where each half florin increment includes a range from 59 sheets (70\%) below the exact increment, up to 25 sheets (30\%) above the exact increment. As a lower number of sheets for a given price increases profit, it is not unexpected that the split is 70/30 and not 50/50. All but one of the folio titles is consistent with this calculation. The exception is Luther's massive fourvolume commentary on Genesis, priced at only 1.05 Pfennig per sheet, which suggests that Montanus \& Neuber may have had excess stock that needed to be sold. The same principle that a single price point could correspond to a varying number of sheets also applied to books priced in Batzen and Ort. In books priced at 12 Batzen or more, the cost per sheet lies between 1.46 and 1.49 Pfennig per sheet, thus approximating a nominal cost of 1.5 Pfennig per sheet.

What determined the choice of denomination? Patterns between types of books and pricing suggest that some formats or types of books were considered premium products: ${ }^{27}$

Books listed by number of sheets:

- None of the Latin folios or quartos

- Nine of the sixteen German folios

- All but one of the German quartos 
Table 11.1 Relationship between pricing in Florins and number of sheets

\begin{tabular}{lllllll}
\hline Florins & $\begin{array}{l}\text { Florins } \\
\text { converted } \\
\text { to Pfennig }\end{array}$ & $\begin{array}{l}\text { Price converted } \\
\text { to sheets at 1.5 } \\
\text { Pfennig per } \\
\text { sheet }\end{array}$ & $\begin{array}{l}\text { Minimum } \\
\text { number of } \\
\text { sheets at each } \\
\text { price }\end{array}$ & $\begin{array}{l}\text { Price/ } \\
\text { sheet }\end{array}$ & $\begin{array}{l}\text { Maximum } \\
\text { number of } \\
\text { sheets at each } \\
\text { price }\end{array}$ & Price/sheet \\
\hline 0.5 & 126 & 84 & 25 & 5.0 & 109 & 1.2 \\
1 & 252 & 168 & 109 & 2.3 & 193 & 1.3 \\
1.5 & 378 & 252 & 193 & 2.0 & 277 & 1.4 \\
2 & 504 & 336 & 277 & 1.8 & 361 & 1.4 \\
2.5 & 630 & 420 & 361 & 1.7 & 445 & 1.4 \\
\hline
\end{tabular}

- All but one of the octavos, duodecimos $\left(12^{\mathrm{mo}}\right)$, sextodecimos $\left(16^{\mathrm{mo}}\right)$ and trigesimosecundos $\left(32^{\mathrm{mo}}\right)$ regardless of language, but none of the editions in these formats of polyphonic music

- All 'Scholasticalia' (including all music theory)

Books priced in Florins, Ort, Batzen or Pfennig:

- All Latin folios and quartos

- The only Czech folio

- Seven of the sixteen German folios

- One of the German quartos

- One of the German octavos

- All polyphonic music editions

There is a pattern for instances where some of a type of book are priced in sheets and others priced in currency. The German folios aimed at institutional or commercial purchasers, such as Luther's Kirchen Postilla or the Handel Buch are priced in currency, but those aimed at personal purchasers, such as Luther's Haußpostill or Veit Dietrich's Kinder Postill are priced in sheets. The only German quarto priced in currency is Johannes Mathesius' Leychpredigten; that the firm had a particular relationship with Mathesius is demonstrated by the only records from before 1600 relating to the firm or its successors applying for an Imperial privilege are for writings by Mathesius. ${ }^{28}$ The only octavo priced in currency, the first edition of a book on making fireworks, has many specialised woodcut illustrations. ${ }^{29}$

\section{Format and language}

An examination of the formats shows that half of the titles listed were in octavo, with about a quarter of titles in larger formats, and a quarter in smaller formats (see Table 11.2); most of the titles in smaller formats, including all of the smaller format music, were Germantexted. On fol. $6^{\mathrm{v}}$, the catalogue refers to 'Columlein', which refers to the imposition of the pages on a sheet of paper, and hence format. ${ }^{30}$

\section{Survivals and losses}

The catalogue provides information on the factors that determine the survival or loss of books. The task of identifying whether or not a particular edition survives in at least one exemplar is ongoing, as the holdings of smaller libraries slowly appear in bibliographies 
and in online catalogues. If editions presently considered to be lost are rediscovered, the calculations in this section may change slightly.

There is a direct correlation between the size of a book and its chances of survival. If we look at format, that is, size calculated by the dimensions of page, folios are the most likely to survive and the tiny $32^{\mathrm{mo}}$ volumes, at only $7.5 \times 5 \mathrm{~cm}$, the least likely (see Table 11.3). If we look at the number of sheets (which is also correlated with the price), we also see that the editions printed on more than fifteen sheets have a much higher survival rate than those printed on fifteen or fewer sheets (see Table 11.4). Whichever method we use to calculate size, we can conclude that bigger books are more likely to survive than smaller

Table 11.2 Distribution of formats

\begin{tabular}{lrrrrrrrr}
\hline Format & \multicolumn{1}{c}{ Latin } & \multicolumn{1}{c}{$\%$} & \multicolumn{1}{c}{ German } & \multicolumn{1}{c}{$\%$} & Polyphonic music & $\%$ & Total & \multicolumn{1}{c}{$\%$} \\
\hline $2^{\circ}$ & 8 & 4.2 & 16 & 8.4 & 0 & 0.0 & 24 & 12.6 \\
$4^{\circ}$ & 5 & 2.6 & 8 & 4.2 & 7 & 3.7 & 20 & 10.5 \\
$8^{\circ}$ & 44 & 23.2 & 46 & 24.1 & 4 & 2.1 & 94 & 49.5 \\
$12^{\text {mo }}$ & 4 & 2.1 & 34 & 17.8 & 0 & 0.0 & 38 & 20.0 \\
$16^{\text {mo }}$ & 2 & 1.0 & 6 & 3.1 & 1 & 0.5 & 9 & 4.7 \\
$32^{\text {mo }}$ & 0 & 0.0 & 5 & 2.6 & 0 & 0.0 & 5 & 2.6 \\
Total & $\mathbf{6 3}$ & $\mathbf{3 3 . 2}$ & $\mathbf{1 1 5}$ & $\mathbf{6 0 . 5}$ & $\mathbf{1 2}$ & $\mathbf{6 . 3}$ & $\mathbf{1 9 0}$ & $\mathbf{1 0 0 . 0}$ \\
\hline
\end{tabular}

Table 11.3 Editions surviving in at least one exemplar, analysed by format

\begin{tabular}{|c|c|c|c|c|c|c|c|c|c|c|}
\hline Format & Latin & $\begin{array}{l}\text { Latin } \\
\%\end{array}$ & German & $\begin{array}{l}\text { German } \\
\%\end{array}$ & $\begin{array}{l}\text { Polyphonic } \\
\text { music }\end{array}$ & $\begin{array}{l}\text { Polyphonic } \\
\text { music \% }\end{array}$ & Total & $\begin{array}{l}\text { Total } \\
\%\end{array}$ & $\begin{array}{l}\text { Music } \\
\text { partbooks } \\
\text { (complete) }\end{array}$ & $\begin{array}{l}\text { Music } \\
\text { partbooks } \\
\text { (complete) \% }\end{array}$ \\
\hline $2^{\circ}$ & 8 of 8 & 100 & 15 of 16 & 94 & 0 of 0 & & 23 of 24 & 96 & & \\
\hline $4^{\circ}$ & 5 of 5 & 100 & 6 of 8 & 75 & 7 of 7 & 100 & 18 of 20 & 90 & 78 of 79 & 99 \\
\hline $8^{\circ}$ & 35 of 44 & 80 & 37 of 46 & 80 & 3 of 4 & 75 & 75 of 94 & 80 & 32 of 36 & 89 \\
\hline $12^{\mathrm{mo}}$ & 3 of 4 & 75 & 15 of 34 & 44 & 0 of 0 & & 18 of 38 & 47 & & \\
\hline $16^{\mathrm{mo}}$ & 0 of 2 & 0 & 0 of 6 & 0 & 1 of 1 & 100 & 1 of 9 & 11 & 2 of 4 & 50 \\
\hline $32^{\mathrm{mo}}$ & 0 of 0 & 0 & 0 of 5 & 0 & 0 of 0 & & 0 of 5 & 0 & & \\
\hline
\end{tabular}

Table 11.4 Editions surviving in at least one exemplar, analysed by the number of sheets in one complete copy of an edition

\begin{tabular}{llll}
\hline number of sheets & total number of titles & $\begin{array}{l}\text { number of surviving } \\
\text { editions }\end{array}$ & $\begin{array}{l}\text { percentage of } \\
\text { editions that survive }\end{array}$ \\
\hline $35.1+$ & 48 & 43 & 90 \\
$30.1-35$ & 11 & 9 & 82 \\
$25.1-30$ & 1 & 1 & 100 \\
$20.1-25$ & 17 & 14 & 82 \\
$15.1-20$ & 15 & 14 & 93 \\
$10.1-15$ & 33 & 19 & 58 \\
$5.1-10$ & 29 & 15 & 52 \\
$1-5$ & 33 & 17 & 52 \\
\hline
\end{tabular}


books. However, length and breadth (format) are a much stronger determinant of survival than thickness (number of sheets), probably because books printed on a small number of sheets were often bound together in a single volume, thus vitiating the 'thickness effect' of the individual titles in a convolute volume.

There is thus a correlation between what has survived and the decisions taken by printers and publishers regarding the format in which they printed and - at least for anthologies - the cumulative length of the work being printed. A further factor is also at work. It seems that collectors preferred editions in octavo or larger formats, and that which was collected has a greater chance of survival.

This hypothesis is borne out by the rate of survival of partbooks of polyphonic music printed by Montanus \& Neuber. The twelve entries of polyphonic music in their catalogue consist of a total of 119 partbooks. Of these, a total of 112 survive in at least one complete exemplar, two survive incomplete and only five are completely lost. Of those that are lost, one was printed in quarto, one in sextodecimo and three were a set partbooks, probably in octavo format, in which the entire set was printed on four sheets (that is, only one or two sheets per partbook). This unusually high survival rate of at least one exemplar may be a result of the fact that almost all are in octavo or larger format, typically consisting of a larger number of sheets, and all having premium pricing.

This finding has significant implications for the survival of polyphonic music and music theory. Polyphonic music in the German-speaking area was almost always printed in relatively larger formats: quarto, and to a lesser extent octavo. Only rarely were music books printed in folio (the Liber selectarum cantionum is such an exception), sexto (Oeglin's songbooks) or formats smaller than octavo (mostly the duodecimos of Peter Schöffer the Younger, and the sextodecimos of Egenolff and Montanus \& Neuber; none of the sets of sextodecimo partbooks survives complete). This implies that polyphonic music editions would be expected to have a higher survival rate that the average rate of survival of all editions, simply because of their size.

Books of music theory (whether learned treatises or instructional works) were printed, by the time that the firm of Montanus \& Neuber was founded, most commonly in octavo, then quarto and then folio. The typical format of such books also changed over time; in the early sixteenth century, such school textbooks were usually in quarto, while octavo format became more popular as the century wore on. The $v d m$ catalogue lists five works on music theory in folio, seventy-five in quarto, seven in oblong quarto, two in oblong sexto, 105 in upright octavo format, but none in $12^{\mathrm{mo}}$ or $16^{\mathrm{mo}}$. Some $47 \%$ of Montanus \& Neuber's $12^{\mathrm{mo}}$ editions and $11 \%$ of the $16^{\mathrm{mo}}$ editions survive. From this we might suppose that if any books of music theory were printed in duodecimo format, some of them would have survived: but there are none known. This suggests that these tiny formats were not used for music-theory editions. The higher survival rates for larger formats imply that music-theory editions have a higher survival rate than the average survival rate for all books (regardless of size).

\section{Polyphonic music books}

As mentioned above, the final page of the catalogue is devoted to 'Musici Libri', all of which are polyphonic music books. Of the twelve titles, ten have long been known, and an eleventh, the De laude musices from 1556 [12.07], can now be added to music bibliographies. The sole known exemplar (DAT5; missing B) came to light when it was purchased by the British Library in 2001. This edition, not in RISM online, is described in Appendix 11.1. 
The collection contains seventeen settings of texts in praise of music, including six settings of 'Musica Dei donum' and four settings - thee of which are unica - of Georg Fabricius' poem 'Divina res est Musica'. These two texts had previously been published by Montanus \& Neuber in 1549 on the final leaf $\left(f \circ l . Q^{r-v}\right)$ of the inferior vox of the Diphona amoena et florida, which was edited by Erasmus Rotenbucher. ${ }^{31}$ Two other texts are set multiple times: 'Decantabat populus' in two settings, both of which had been previously published; and 'Laeta graves abigit' in two settings, both of which are unica. ${ }^{32}$ Seven of the seventeen compositions appear to be unica; of particular interest for the compilation of this edition is that three of the unica are by composers with an association with Heidelberg: Caspar Othmayr, Gregor Peschin and Stephan Zirler. ${ }^{33}$ The other ten motets had been previously published: seven in Susato's Liber ... ecclesiasticarum cantionum (vols. 2, 3, 8, 9 and 10, published between 1553 and 1555), and three in other editions.

The lost edition, the Oratio Didonis tribus vocibus [12.12.], was given at the price of 6 Pfennig, and thus presumably contained four sheets, one or two sheets for each of the three partbooks. Montanus \& Neuber printed all of their known editions of two-voice and three-voice compositions in octavo, which suggests that this edition may have also been an octavo. From the title, we may assume that the edition contained settings of texts from book 4 of Vergil's Aeneid, and given number of leaves in each partbook and the inclusion of multiple settings of the same text in De laude musices, it is probable that the edition contained more than one motet. There are two extant three-voice motets that would be suitable for inclusion: both are settings of 'Dulces exuviae', one by Gregor Peschin (D-Rp B 220-222, no. 29) and the other transmitted anonymously in Georg Rhau's Tricinia (RISM $1542^{8}$, no. 50; there are multiple concordances).

It is noteworthy that the multi-volume sets such as the six-volume Evangelia [12.01], the five Forster Lied Anthologies [12.04] and the three-volume Magnus opus musicum [12.03], were only available as complete sets - of thirty, twenty-one and fifteen partbooks respectively. There was no pricing for individual volumes.

Table 11.5, which lists the editions of polyphony produced by Montanus \& Neuber, shows that most editions published after 1547 are included in the catalogue; the only editions not included are those for two or three voices (the bicinia and tricinia), and very slender books for special occasions - for example, the Proteleios euchē, which consists of four leaves of quarto per partbook and may have been a private commission and so not offered for general sale. Several editions in the catalogue, all anthologies of Lieder, were reprints of earlier editions; the earlier editions are indicated in the table by a superscript letter ' $E$ ' after the catalogue number, and later editions are indicated by a superscript letter ' $R$ '. Unlike the rest of the catalogue, the titles in this section, 'Musici libri', are not arranged by (and do not give) the format, which is supplied editorially in Appendix 11.2, nor by language, but appear to be ordered by price from highest to lowest (with two editions, numbers [12.07] and [12.10], being out of order).

\section{Music theory}

Music-theory books are represented by three titles listed at the end of the section for school books ('Scholasticalia'). All are listed by number of sheets. This tells us that music theory at least when printed in octavo editions - did not carry premium pricing.

Table 11.6 (p. 259 below) is a list of all Montanus \& Neuber music-theory books up to and including 1563. Two theoretical treatises known to have been printed by Montanus \& Neuber are not included in the catalogue, and had presumably sold out: Heinrich Faber's 
Table 11.5 All known polyphonic music printed by Montanus \& Neuber

\begin{tabular}{|c|c|c|c|c|c|}
\hline $\begin{array}{l}\text { M\&N } \\
\text { Cat. No }\end{array}$ & Year & $v d m$ & RISM & Composer or editor & Standardised short title \\
\hline- & 1544 & 1027 & $1544^{20}$ & Hans Ott, ed. & 115 guter newer Liedlein \\
\hline- & 1546 & 1110 & $1546^{8}$ & $\begin{array}{l}\text { Johannes Montanus, } \\
\text { ed. }\end{array}$ & $\begin{array}{l}\text { Selectissimae symphoniae } \\
\text { compositae }\end{array}$ \\
\hline- & 1546 & 1039 & O 258 & Caspar Othmayr & Cantilenae aliquot elegantes \\
\hline- & 1546 & 1038 & O 259 & Caspar Othmayr & Epitaphium D. Martini Lutheri \\
\hline- & 1547 & 1117 & O 260 & Caspar Othmayr & $\begin{array}{l}\text { Bicinia sacra: Schöne geistliche } \\
\text { Lieder }\end{array}$ \\
\hline- & 1547 & 1168 & O 261 & Caspar Othmayr & $\begin{array}{l}\text { Symbola illustrissimorum } \\
\text { principum }\end{array}$ \\
\hline 12.5 & 1549 & 1120 & $1549^{1}$ & Kaspar Brusch, ed. & $\begin{array}{l}\text { Lamentationes Hieremiae } \\
\text { Prophetae }\end{array}$ \\
\hline- & 1549 & 1122 & $1549^{16}$ & $\begin{array}{l}\text { Erasmus Rotenbucher, } \\
\text { ed. }\end{array}$ & $\begin{array}{l}\text { Diphona amoena et florida } \\
\text { [bicinia] }\end{array}$ \\
\hline $12.4^{\mathrm{E}}$ & 1549 & 1130 & $1549^{35}$ & Georg Forster, ed. & Teutsche Liedlein 1 \\
\hline $12.4^{\mathrm{E}}$ & 1549 & 1134 & $1549^{36}$ & Georg Forster, ed. & Teutsche Liedlein 2 \\
\hline $12.4^{\mathrm{E}}$ & 1549 & 1135 & $1549^{37}$ & Georg Forster, ed. & Teutsche Liedlein 3 \\
\hline- & 1549 & 1169 & O 262 & Caspar Othmayr & Tricinia in pias aliquot \\
\hline $12.9^{\mathrm{E}}$ & 1549 & 1143 & O 263 & Caspar Othmayr & $\begin{array}{l}\text { Reutterische und jegerische } \\
\text { Liedlein }\end{array}$ \\
\hline $12.9^{\mathrm{E}}$ & $\begin{array}{l}\text { [between } \\
1549 \text { and } \\
1559]\end{array}$ & 1142 & [c. 1550$]^{22}$ & Caspar Othmayr & $\begin{array}{l}\text { Reutterische und jegerische } \\
\text { Liedlein }\end{array}$ \\
\hline 12.6 & 1550 & 1137 & $1550^{2}$ & Kaspar Brusch, ed. & Carmina vere divina \\
\hline- & 1551 & & $1551^{20}$ & $\begin{array}{l}\text { Erasmus Rotenbucher, } \\
\text { ed. }\end{array}$ & $\begin{array}{l}\text { Bergkreyen auff zwo Stimmen } \\
\text { componirt }\end{array}$ \\
\hline- & 1551 & & $\begin{array}{l}\text { RR } 1814 \\
\text { I,1 }\end{array}$ & Joannes Rodestoggius & $\begin{array}{l}\text { Bicinia sacra: Geistliche Lieder } \\
\text { und Psalmen }\end{array}$ \\
\hline $12.4^{\mathrm{E}}$ & 1552 & & $1552^{27}$ & Georg Forster, ed. & Teutsche Liedlein 1 \\
\hline 12.4 & 1552 & & $1552^{28}$ & Georg Forster, ed. & Teutsche Liedlein 3 \\
\hline 12.8 & 1552 & & C 3258 & Adrianus Petit Coclico & Consolationes ex psalmis \\
\hline 12.2 & 1553 & & $1553^{4}$ & $\begin{array}{l}\text { Johannes Montanus, } \\
\text { ed. }\end{array}$ & Psalmi selecti 1 \\
\hline 12.2 & 1553 & & $1553^{5}$ & $\begin{array}{l}\text { Johannes Montanus, } \\
\text { ed. }\end{array}$ & Psalmi selecti 2 \\
\hline 12.2 & 1553 & & $1553^{6}$ & $\begin{array}{l}\text { Johannes Montanus, } \\
\text { ed. }\end{array}$ & Psalmi selecti 3 \\
\hline 12.4 & 1553 & & $1553^{30}$ & Georg Forster, ed. & Teutsche Liedlein 2 \\
\hline- & [1553] & & {$[1554]^{30}$} & & In Epitaphiis Gasparis Othmari \\
\hline 12.1 & 1554 & & $1554^{10}$ & $\begin{array}{l}\text { Johannes Montanus, } \\
\text { ed. }\end{array}$ & Evangelia 1 \\
\hline 12.2 & 1554 & & $1554^{11}$ & $\begin{array}{l}\text { Johannes Montanus, } \\
\text { ed. }\end{array}$ & Psalmi selecti 4 \\
\hline 12.1 & 1555 & & $1555^{10}$ & $\begin{array}{l}\text { Johannes Montanus, } \\
\text { ed. }\end{array}$ & Evangelia 2 \\
\hline 12.1 & 1555 & & $1555^{11}$ & $\begin{array}{l}\text { Johannes Montanus, } \\
\text { ed. }\end{array}$ & Evangelia 3 \\
\hline 12.1 & 1555 & & $1555^{12}$ & $\begin{array}{l}\text { Johannes Montanus, } \\
\text { ed. }\end{array}$ & Evangelia 4 \\
\hline 12.1 & 1556 & & $1556^{8}$ & $\begin{array}{l}\text { Johannes Montanus, } \\
\text { ed. }\end{array}$ & Evangelia 5 \\
\hline
\end{tabular}


Table 11.5 continued

\begin{tabular}{|c|c|c|c|c|c|}
\hline $\begin{array}{l}\text { M\&N } \\
\text { Cat. No }\end{array}$ & Year & $v d m$ & RISM & Composer or editor & Standardised short title \\
\hline 12.1 & [1556] & & {$[1556]^{9}$} & $\begin{array}{l}\text { Johannes Montanus, } \\
\text { ed. }\end{array}$ & Evangelia 6 \\
\hline 12.4 & 1556 & & $1556^{28}$ & Georg Forster, ed. & Teutsche Liedlein 4 \\
\hline 12.4 & 1556 & & $1556^{29}$ & Georg Forster, ed. & Teutsche Liedlein 5 \\
\hline 12.7 & 1556 & & $\begin{array}{l}\text { Not in } \\
\text { RISM }\end{array}$ & $\begin{array}{l}\text { Johannes Montanus, } \\
\text { ed. }\end{array}$ & De laude musices \\
\hline 12.3 & 1558 & & $1558^{4}$ & $\begin{array}{l}\text { Johannes Montanus, } \\
\text { ed. }\end{array}$ & Novum opus musicum 1 \\
\hline 12.3 & 1559 & & $1559^{1}$ & $\begin{array}{l}\text { Johannes Montanus, } \\
\text { ed. }\end{array}$ & Novum opus musicum 2 \\
\hline 12.3 & 1559 & & $1559^{2}$ & $\begin{array}{l}\text { Johannes Montanus, } \\
\text { ed. }\end{array}$ & Novum opus musicum 3 \\
\hline 12.9 & 1559 & 1141 & [c. 1550$]^{23}$ & Caspar Othmayr & $\begin{array}{l}\text { Reütterische und jägerische } \\
\text { Liedlein }\end{array}$ \\
\hline 12.11 & 1559 & & L 1841 & Mattheus Le Maistre & Catechesis numeris musicis \\
\hline 12.10 & [1560] & & {$[1560]^{1}$} & $\begin{array}{l}\text { Johannes Montanus, } \\
\text { ed. }\end{array}$ & Selectissimorum triciniorum 1 \\
\hline 12.10 & 1560 & & $1560^{2}$ & $\begin{array}{l}\text { Johannes Montanus, } \\
\text { ed. }\end{array}$ & Selectissimorum triciniorum 2 \\
\hline 12.10 & [1560] & & F 720 & Wolfgang Figulus & $\begin{array}{l}\text { Selectissimorum triciniorum } 3 \\
\text { [dedication dated 1559] }\end{array}$ \\
\hline 12.4 & 1560 & & $1560^{25}$ & Georg Forster, ed. & Teutsche Liedlein 1 \\
\hline- & 1561 & & D 1728 & Michel Desbuissons & Epithalamia duo in nuptijs \\
\hline- & 1561 & & $1561^{1}$ & Christoph Schweher & Veteres ac piae cantiones \\
\hline- & 1562 & & L 768 & Orlando di Lasso & Sacrae cantiones $5 v$ \\
\hline $12.10^{\mathrm{R}}$ & 1563 & & $1563^{2}$ & Wolfgang Figulus, ed. & Selectissimorum triciniorum 3 \\
\hline $12.04^{\mathrm{R}}$ & 1563 & & $1563^{17}$ & Georg Forster, ed. & Teutsche Liedlein 3 \\
\hline- & 1563 & & L 775 & Orlando di Lasso & Sacrae cantiones $5 v$ \\
\hline $12.11^{\mathrm{R}}$ & 1563 & & L 1842 & Mattheus Le Maistre & Catechesis numeris musicis \\
\hline- & [undated] & 1139 & $1550^{21}$ & $\begin{array}{l}\text { Andreas Schwartz, } \\
\text { Jakob Meiland }\end{array}$ & $\begin{array}{l}\text { Protelios euchē, qua chorus } \\
\text { musicus }\end{array}$ \\
\hline 12.12 & [lost] & & & [lost $]$ & Oratio Didonis tribus uocibus \\
\hline
\end{tabular}

The date 1559 and title for Cat. 12.9 are from Charteris, Werdenstein, 179.

Ad musicam practicam introductio, which they printed once in 1550, was presumably superseded by Faber's Compendiolum musicae (1555 and later editions). The other theory edition no longer available was Coclico's Compendium musices, but its accompanying music edition [12.08] was still available.

\section{Editions containing Kirchenlieder}

The catalogue includes six editions containing Kirchenlieder; one of those editions additionally contains Latin-texted liturgical music. These appear under the format and language headings, where they are mixed in with non-music books (see Table 11.7).

If we examine them in the order in which they appear in the catalogue, the first is the Kirchenordnung of Wolfgang Pfalzgraf Pfalz-Zweibrücken [2.07]. Although Montanus \& 
Table 11.6 All known music-theory books printed by Montanus \& Neuber

\begin{tabular}{|c|c|c|c|c|c|c|}
\hline $\begin{array}{l}\text { M\&N } \\
\text { Cat. No }\end{array}$ & Year & $v d m$ & RISM & Author & Standardised short title & Leaves \\
\hline & 1550 & 1322 & B VI, 301 & Heinrich Faber & Ad musicam & 96 \\
\hline \multirow[t]{2}{*}{5.21} & {$[155 \mathrm{X}]$} & 1309 & B VI, 509 & Nicolaus Listenius & Musica & 44 \\
\hline & 1552 & & B VI, 227 & $\begin{array}{l}\text { Adrianus Petit } \\
\text { Coclico }\end{array}$ & Compendium musices & 60 \\
\hline $5.22^{\mathrm{E}}$ & 1555 & & B VI, 302 & Heinrich Faber & Compendiolum musicae & 16 \\
\hline $5.22^{\mathrm{E}}$ & 1557 & & B VI, 302 & Heinrich Faber & Compendiolum musicae & 16 \\
\hline 5.22 & 1558 & & B VI, 302 & Heinrich Faber & Compendiolum musicae & 16 \\
\hline \multirow[t]{2}{*}{5.23} & 1560 & & $\begin{array}{l}\text { B VI, } 69 \\
\text { DKL } 1560^{02}\end{array}$ & $\begin{array}{l}\text { Martin Agricola, ed. } \\
\text { Wolfgang Figulus }\end{array}$ & Deutsche Musica & 112 \\
\hline & 1561 & & B VI, 893 & $\begin{array}{l}\text { Ambrosius } \\
\text { Wilfflingseder }\end{array}$ & Musica Teutsch & 56 \\
\hline & 1562 & & B VI, 509 & Nicolaus Listenius & Musica & 44 \\
\hline \multirow[t]{2}{*}{$5.23^{R}$} & 1563 & & $\begin{array}{l}\text { B VI, } 69 \\
\text { DKL } 1563^{01}\end{array}$ & $\begin{array}{l}\text { Martin Agricola, ed. } \\
\text { Wolfgang Figulus }\end{array}$ & Deutsche Musica & 112 \\
\hline & 1563 & & B VI, 517 & Lucas Lossius & Erotemata musicae & 112 \\
\hline
\end{tabular}

Table 11.7 All known editions containing monophonic liturgical music or hymns printed by Montanus \& Neuber

\begin{tabular}{|c|c|c|c|c|c|}
\hline $\begin{array}{l}\text { M\&N } \\
\text { Cat. No/ } \\
{ }^{*} \text { Heyden }\end{array}$ & Year & $v d m$ & $\begin{array}{l}\text { RISM or } \\
\text { VD16 }\end{array}$ & Composer or editor & Standardised short title \\
\hline * & $\begin{array}{l}1542 \\
\text { [after } \\
1542]\end{array}$ & $\begin{array}{l}1253 \\
1263\end{array}$ & $\begin{array}{l}1542^{08} \\
1543^{06}\end{array}$ & $\begin{array}{l}\text { Hans Gamersfelder } \\
\text { Sebald Heyden }\end{array}$ & $\begin{array}{l}\text { Der gantz Psalter Davids } \\
\text { Ein Lobgesang }\end{array}$ \\
\hline $3.07^{\mathrm{E}}$ & 1543 & 1147 & & Veit Dietrich & Agend Büchlein \\
\hline $3.07^{\mathrm{E}}$ & 1543 & 1148 & & Veit Dietrich & Agend Büchlein \\
\hline *E & 1544 & 1280 & $1544^{09}$ & Sebald Heyden & $\begin{array}{l}\text { Die Einsetzung ... des heyligen } \\
\text { Abentmals }\end{array}$ \\
\hline $3.07^{\mathrm{E}}$ & 1544 & 1151 & & Veit Dietrich & Agend Büchlein \\
\hline * & 1545 & 1286 & $1545^{07}$ & Sebald Heyden & Der christliche Glaub \\
\hline $3.07^{\mathrm{E}}$ & 1545 & 1152 & $1545^{10}$ & Veit Dietrich & Agend Büchlein \\
\hline * & [1546] & 1336 & $1546^{03}$ & Sebald Heyden & Der lxxx Psalm \\
\hline $3.07^{\mathrm{E}}$ & 1548 & 1155 & $1548^{06}$ & Veit Dietrich & Agend Büchlein \\
\hline$* \mathrm{E}$ & [1548] & 1125 & R 1198 & Sebald Heyden, ed. & Liber canticorum \\
\hline * & 1549 & 1347 & $1549^{05}$ & Sebald Heyden & Der lxvj Psalm \\
\hline * & [1549] & 1559 & & Sebald Heyden & $\begin{array}{l}\text { Die Einsetzung ... des heyligen } \\
\text { Abentmals }\end{array}$ \\
\hline * E & 1550 & 1126 & ZV 13102 & Sebald Heyden, ed. & Liber canticorum \\
\hline $6.22^{\mathrm{E}}$ & [c. 1552] & $1132 ?$ & $1552^{01}$ & Jan Roh & $\begin{array}{l}\text { Gesangbuch der Brüder in } \\
\text { Behemen und Merherrn }\end{array}$ \\
\hline $9.01^{\mathrm{E}} ?$ & 1553 & & $1553^{05}$ & $\begin{array}{l}\text { Martin Luther } \\
\text { (Preface) }\end{array}$ & Geistliche Lieder zu Wittenberg \\
\hline $3.07^{\mathrm{E}}$ & 1553 & & $1553^{08}$ & Veit Dietrich & Agend Büchlein \\
\hline $3.07^{\mathrm{E}}$ & 1553 & & $1553^{09}$ & Veit Dietrich & Agend Büchlein \\
\hline $6.22^{\mathrm{E}}$ & [c. 1554] & & $1554^{01}$ & Jan Roh & $\begin{array}{l}\text { Gesangbuch der Brüder in } \\
\text { Behemen und Merherrn }\end{array}$ \\
\hline
\end{tabular}


Table 11.7 continued

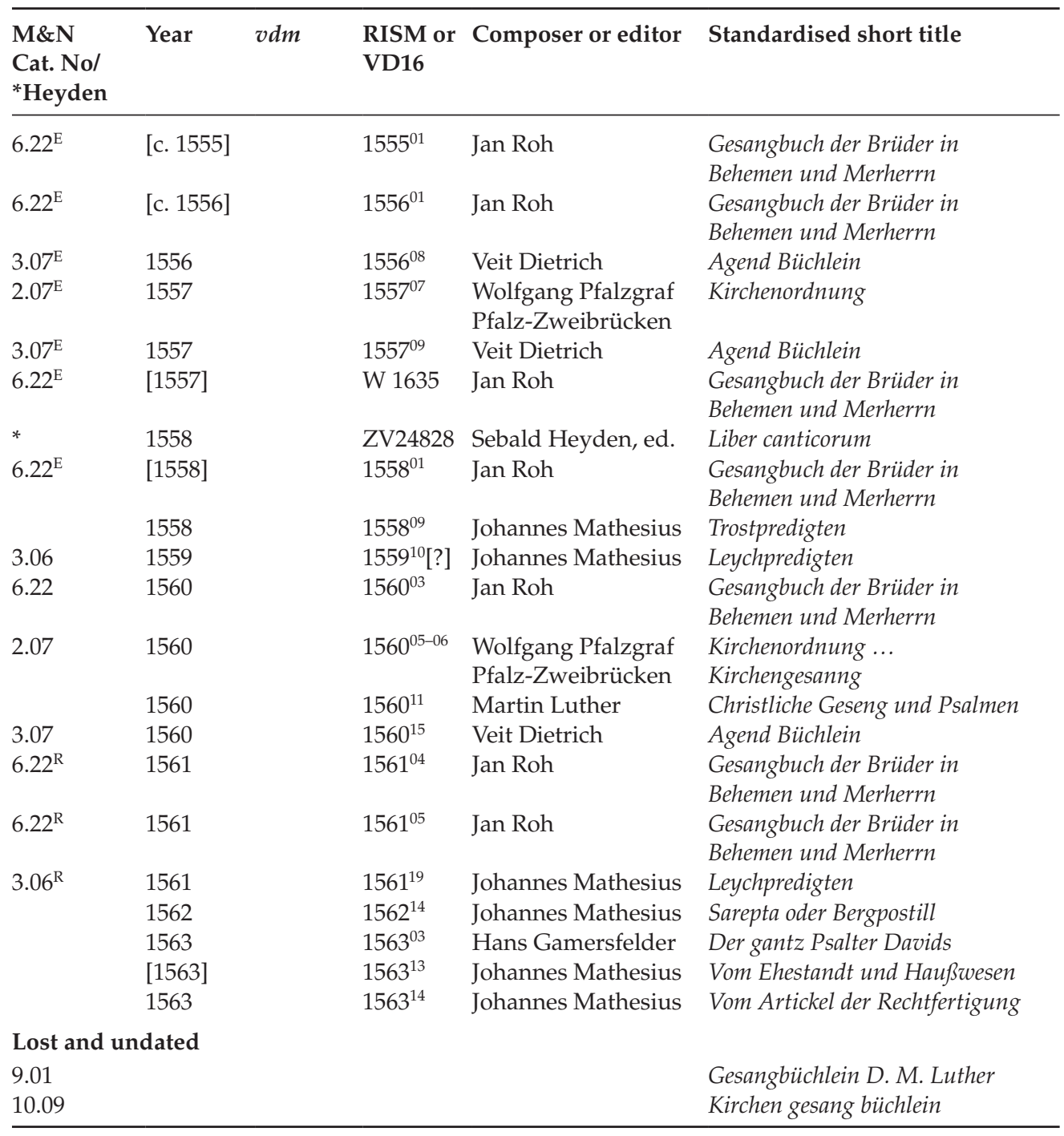

Neuber are named as printers in the 1557 edition, they are not named as printers in the 1560 edition; however, the secondary literature, including the VD16 and Claus' MelanchthonBibliographie (1560.79), assigns this edition to them. RISM DKL gives the format of both editions as quarto, but in fact they are folios signed and gathered in fours. The edition is in two parts, each with a separate series of foliation (beginning 1) and signatures (beginning a); the second part is devoted to music. Folios $2^{r}-65^{v}$ contain German-texted monophonic music in white mensural notation, and folios $66^{\mathrm{r}}-93^{\mathrm{r}}$ print Latin-texted monophonic music in Gothic chant notation. This is followed by ten pieces of four-voice homophonic music (Discantus, Altus, Tenor, Bassus): 'Isometra symphona ad Psalmum quemlibet accommodabilis' in the first and fifth tones on folios $93^{\mathrm{v}}-95^{\mathrm{r}}$, and a set of eight Magnificats, one in each of the eight tones, on folios $95^{\mathrm{v}}-119^{\mathrm{r}}$. This edition is set at premium pricing, here in Batzen at 1.45 Pfennigs per sheet. Half of the German editions in folio format have premium pricing, and it cannot be determined whether or not in this instance the pricing 
resulted from the inclusion of printed music. However, as three of the volumes discussed below consisted mostly of printed music (including one using both white mensural and Gothic chant typefaces), but are not set at premium pricing, it is more likely that the association with the Pfalzgraf was the decisive factor.

The next item is the Leychpredigten of Johannes Matthesius [3.06]. This is the only upright German quarto in the catalogue that is not listed by number of sheets but priced in Batzen, which implies that the publisher wished to single out this volume as being of special significance. Of its some 600 pages, only three have printed music (fol. Aa2 ${ }^{\mathrm{v}}, \mathrm{Pp}^{\mathrm{r}}$ and $\left.\operatorname{Dddd} 2^{v}\right)$, in each case a single monophonic hymn. It was printed on 75.5 sheets and is priced at 5 Batzen, approximately 1 Pfennig per sheet to the nearest Batzen. ${ }^{34}$

Item [3.07] is the Agenda Viti. The edition of 1560 comprises 124 leaves in quarto, that is, thirty-one sheets, which matches the number of sheets stated in the catalogue. Montanus \& Neuber had printed at least nine earlier editions of this work, making this title one of their bestsellers. As this work was likely to be updated regularly, it was necessary to reprint it regularly, rather than printing larger editions.

The title 'Der Picarden Gesangbuch' [6.22] surely refers to Ein Gesangbuch der Brüder inn Behemen vnnd Merherrn, Die man auß haß ond neyd, Pickharden, Waldenses, Ec. nennet. The 1560 edition has 248 leaves of octavo, which matches the catalogue description of thirtyone sheets. Again, this was a bestseller, having been through at least six earlier editions. Like the Kirchenordnung, two music typefaces are used in this edition: white mensural and Gothic chant.

The 'Gesangbüchlein D. M. Luther' [9.01] cannot be identified as extant. We can calculate from the format (duodecimo) and number of sheets (thirty-two) that we are looking for a substantial volume of about 384 leaves. Georg Serpilius, in the section of his LiederGedancken devoted to Nuremberg, lists a 'Gesangbüchlein/ darinnen der gantze Psalter Davids nach Ordnung der Psalmen/ sammt andern geistlichen Gesängen mit ihren Melodeyen begriffen/ mit Fleiß übersehen und corrigiret/ 1560. in $12^{\prime} .{ }^{35}$ This edition is no longer extant, and is listed as such as DKL $1560^{10}$. Although there is much that matches - the title, city and format - the omission of Luther's name would be unexpected. In 1553, Montanus \& Neuber had printed a Geistliche Lieder zu Wittemberg (DKL 1553 ${ }^{05}$ ) of 180 leaves in duodecimo, and the present edition may be a significantly expanded edition of that one. On the other hand, in 1562 Valentin Neuber printed a Geystliche Lieder. Mit einer newen Vorrede D. Mart. Luth. (DKL 1562 ${ }^{07}$ ) which was 372 leaves of duodecimo, of which this may be an earlier edition. In any case, this 'Gesangbüchlein D. M. Luther' is evidently lost.

The Kirchen gesang büchlein [10.09] in sextodecimo and printed on seven sheets would have been of 112 leaves. This approximates the Kirchengesenge mit vil schönen Psalmen (DKL $1549^{07}$ ) printed in sextodecimo by Valentin Neuber in 1549 , but at 7.5 sheets (and so 120 leaves), that edition is half a sheet larger than expected. Given that the known edition was dated eleven years earlier, and that these small editions were presumably designed to sell quickly, the edition in the catalogue may be a lost reprint of the 1549 edition.

Let us turn briefly to the editions containing hymns printed by Montanus \& Neuber, but which are not in the catalogue, and in particular the many editions by Sebald Heyden, who spent almost his entire life in Nuremberg. Not one of his six different titles containing printed music is included in the catalogue; to make it visually apparent that most of the editions in Table 11.7 that are not in the catalogue are Heyden editions, I have indicated his editions with an asterisk in the column of the table that gives the catalogue numbers. Indeed, only four titles by this prolific author are included, all non-music titles sequentially under the heading 'Scholasticalia'. It is not surprising that his five tiny editions from 
the 1540s containing hymns are not listed, as three of them were only four leaves in duodecimo. The absence of the much more substantial 1558 Liber canticorum (168 leaves, or twenty-one sheets, of octavo), a new edition of a title that Montanus \& Neuber had previously printed in [1548] and 1550, suggests that this work had sold quickly. ${ }^{36}$

\section{Conclusion}

This Montanus \& Neuber catalogue gives us rare evidence of the publisher's price of new unbound music books in the mid-sixteenth century. It demonstrates that, at least for this major printing firm, music theory and monophonic music was priced at the generic level for printed editions, but that volumes of polyphonic music attracted premium pricing, which in this instance was approximately 1.5 Pfennig per sheet. It also tells us that all editions, both generic and premium, were priced directly according to the number of sheets of paper used to print a copy of the edition. While this is not surprising, it is good to have evidence.

The catalogue also provides strong evidence for the forces that guide the survival or loss of individual copies. The most important factors are format and, to a lesser extent, the number of sheets. This is important as catalogues other than those of printers, publishers and booksellers include what was actively collected, which was only a selection of what was on the market. To judge from the catalogues of early collections, the total disappearance of so many tiny books in $12^{\mathrm{mo}}, 16^{\mathrm{mo}}$ and $32^{\mathrm{mo}}$ from the record began soon after their production. The survival of early printed books to our day thus began with decisions taken by the printer or those commissioning the printing, and related to the function and format of the book. Being aware of the loss of these smaller editions is important: Peter Stallybrass has argued that 'Reprints and job printing had to support the deluxe volumes. But the deluxe volumes, surviving in substantial numbers, dominate accounts of the history of printing, while the great majority of broadsides, almanacs, pamphlets, and schoolbooks have disappeared completely ${ }^{37}$ That the Montanus \& Neuber catalogue - an octavo pamphlet of eight leaves - itself survives in only a single exemplar forcefully reminds us of the forces of attrition that acted differently on printed material of different kinds.

\section{Appendix 11.1 De laude musices (Nuremberg: Montanus \& Neuber, 1556)}

Title:

[Black woodcut] De laude Mufices | | [Red type] C A N T I O N E S | | DVLCISSIM $Æ$, A' PRÆSTAN- | | TISSIMIS HVIVS AETATIS MVSICIS, | | [black] Quatuor, Quinq $q_{3}$ \& Sex uocibus || compolitæ. || [Red woodcut in ornamental box] TENOR || [Black type] Noribergæ, in Officina Ioannis Montani, | | \& Vlrici Neuberi. 1556. ||

Titles of other partbooks:

[Woodcut in ornamental box:] DISCANTVS || [Type] IN CANTIONIBVS || DE LAVDE MVSICES. || M. D. LVI. |

[Woodcut in ornamental box:] ALTVS | | [Type] IN CANTIONIBVS || DE LAVDE MVSICES. || M. D. LVI. | |

[lost; inferred: [Woodcut in ornamental box:] BASSVS | | [Type] INCANTIONIBVS | | DE LAVDE MVSICES. || M. D. LVI. ||]

[Woodcut in ornamental box:] VAGANS | | [Type] IN CANTIONIBVS | | DE LAVDE MVSICES. || D. M. LVI. [sic] | |

Colophon: [none]

Format: oblong quarto 
Collation and Signatures: all gatherings except the first have the name of the partbook in the signature line of the first leaf of the gathering:

Tenor:

36 leaves, $\mathrm{a}-\mathrm{i}^{4}$

a $1^{\mathrm{v}}, \mathrm{a} 4^{\mathrm{v}}, \mathrm{i} 4^{\mathrm{v}}$ blank

\$3 signed in Roman lowercase and Arabic numerals (-a1; mis-signing a2-3 in italic, [a4] as aa2)

\section{Discantus:}

36 leaves, AA-II ${ }^{4}$

$\mathrm{AA} 1^{\mathrm{v}}, \mathrm{AA} 2^{\mathrm{v}}, \mathrm{II}^{\mathrm{v}}-4^{\mathrm{v}}$ blank

$\$ 3$ signed in double Roman uppercase and Arabic numerals (-AA1; mis-signing AA2 as aa2; BB3 as bb3)

Altus:

36 leaves, aa- $\mathrm{ii}^{4}$

aa $1^{\mathrm{v}}$, aa2 ${ }^{\mathrm{v}}$, ii $^{\mathrm{v}}-4^{\mathrm{v}}$ blank

$\$ 3$ signed in double Roman lowercase and Arabic numerals (-aa1)

Bassus:

[inferred as 36 leaves, $\mathrm{A}-\mathrm{I}^{4}$ ]

[inferred as \$3 signed in Roman uppercase and Arabic numerals]

Vagans:

20 leaves, $\mathrm{Aa}-\mathrm{Ee}^{4}$

$A a 1^{v}, A_{2}{ }^{v}, E e 3^{v}$ blank (Ee4 missing, presumably blank)

$\$ 3$ signed in Roman uppercase and lowercase and Arabic numerals (-Aa1)

Watermarks:

[letter] K (Tenor gatherings A, E, I; Discantus gatherings A, C, E, G; Altus gatherings B, C, G, I; Vagans no watermarks) ${ }^{\mathrm{a}}$

[letter] $\mathrm{P}$ (Discantus gathering $\mathrm{B})^{\mathrm{b}}$

Exemplar: GB-Lbl K.11.e.21 (missing Bassus; bound in a sixteenth-century binding, whose endpaper bears the heraldic arms of Saxony, along with Veteres ac piae cantiones (Nuremberg: Montanus \& Neuber, 1561; RISM 1561 ${ }^{1}$ ) and Johann Spangenberg, Versus ex hymno de passione Christi (Jena: Richtzenhain, 1561; RISMS 4045); purchased in 2001) Contents (transcribed from the Index in the Tenor partbook; composer names in square brackets are the forms used in $\mathrm{MGG}^{2}$, except for Tylman [not Tielman] Susato):

\begin{tabular}{llll}
\hline$\#$ & Composer & Title & Concordant sources $^{\mathbf{c}}$ \\
\hline & CANTIONES QVINQVE VOCVM & & \\
\hline I & Ioannes Louuys [Jean Louys] & Mufica Dei donum & RISM 1553 \\
II & Ioannes Gallus & Mufica Dei donum & RISM 1554 \\
III & Nicolaus Rogier [Nicolaus Roggius] & Mufica Dei donum & RISM 1554 \\
IV & Ioannes Crefpel [Johannes de & Dauid rex Propheta & RISM 1554 \\
& Crespel] & &
\end{tabular}

a See WZI, type Buchstaben/Ziffern - ein Buchstabe - Buchstabe K - frei, ohne Beizeichen zweikonturig, nicht gebrochen - Schaft gebogen - vollständig zweikonturig - senkrecht. There are two pairs of marks.

b See WZI, type - Buchstaben/Ziffern - Buchstabe P - frei, einfache Form - Schaft zweikonturig, ohne Balken - senkrecht, ohne Beizeichen - ohne Schnörkel - Bogen quadratisch. Between two chainlines, $30.5 \mathrm{~mm}$ apart. The mark is most similar to https://www.wasserzeichen-online.de/ wzis/struktur.php?ref=AT8100-PO-106487 


\begin{tabular}{|c|c|c|c|}
\hline V & $\begin{array}{l}\text { Clemens non Papa [Jacobus } \\
\text { Clemens] }\end{array}$ & Decantabat populus & $\begin{array}{l}12 \text { sources including: } \\
\text { RISM } 1554^{5} \text {, RISM } 1555^{13}\end{array}$ \\
\hline VI & $\begin{array}{l}\text { Ioannes Caftelleti [Jean Guyot de } \\
\text { Châtelet known as Castileti] }\end{array}$ & Decantabat populus & RISM $1555^{8}$ \\
\hline VII & Steffanus Cirlerus [Stephan Zirler] & Læta graues abigit & unicum \\
\hline \multirow[t]{2}{*}{ VIII } & $\begin{array}{l}\text { Antonius Scandellus [Antonio } \\
\text { Scandello] }\end{array}$ & Diuina res eft Mufica & unicum \\
\hline & CANTIO SEX VOCVM & & \\
\hline \multirow[t]{2}{*}{ IX } & Tilmannus Sufato [Tylman Susato] & Mufica Dei donum & RISM $1540^{7}$ \\
\hline & CANTIONES QVATVOR VOCVM & & \\
\hline$x$ & $\begin{array}{l}\text { Clemens non Papa [Jacobus } \\
\text { Clemens] }\end{array}$ & Mufica Dei donum & RISM $1553^{10}$ \\
\hline XI & Iacobus Sothi & Mufica Dei donum & $\begin{array}{l}\text { RISM } 1553^{9}, \text { 'Incertus } \\
\text { author' }\end{array}$ \\
\hline XII & Georgius Pefthin [Gregor Peschin] & Ne impedias Muficam & unicum \\
\hline XIII & Gafpar Othmair [Caspar Othmayr] & Læta graues abigit & unicum \\
\hline XIV & Ioannes Reufchius [Johann Reusch] & Diuina res eft Mufica & RISM R 1210 \\
\hline XV & Heinricus Faber [Heinrich Faber] & Diuina res eft Mufica & unicum \\
\hline XVI & Andreas Schuuartz & $\begin{array}{l}\text { Quid Mufica } \\
\text { præft[antius] }\end{array}$ & unicum \\
\hline XVII & Incerti authoris & Diuina res eft Mufica & unicum \\
\hline
\end{tabular}

'I am grateful to Bonnie Blackburn for bringing the sole concordances to nos. VI, XI and XIV to my attention, and for a reference to XIV in Heidrich, 'Musik und Humanismus', 104. It is interesting that in each instance the motet is the final setting in the concordant edition.

Key:

RISM $1540^{7} \quad$ Selectissimae necnon familiarissimae cantiones (Augsburg: Kriesstein, 1540)

RISM $1553^{9}$ Liber secundus ecclesiasticarum cantionum (Antwerp: Susato, 1553)

RISM $1553^{10} \quad$ Liber tertius ecclesiasticarum cantionum (Antwerp: Susato, 1553)

RISM $1553^{15}$ Liber octavus ecclesiasticarum cantionum (Antwerp: Susato, 1553)

RISM R 1210 Melodiae odarum Georgii Fabricii: compositae a M. Iohanne Reuschio Rotachense (Leipzig: Gunther, 1554)

RISM $1554^{5} \quad$ Liber sextus cantionum sacrarum vulgo moteta vocant (Louvain: Phalèse, 1554)

RISM $1554^{9} \quad$ Liber nonus ecclesiasticarum cantionum (Antwerp: Susato, 1554)

RISM $1555^{8}$ Liber decimus ecclesiasticarum cantionum (Antwerp: Susato, 1555)

RISM $1555^{13}$ Tertius liber modulorum, 4, 5, et 6 vocum (Geneva: Dubosc \& Guéroult, 1555)

\section{Appendix 11.2 Edition of the catalogue}

The Transcription, Price and the Latin or German headings for each of the sections are transcribed from the catalogue. All other columns are editorial; authors' names are standardised as given in VD16. RISM numbers are only given when the edition is not included in VD16. The words Florin, Groschen, and chartae (sheets of paper), abbreviated in the catalogue as the initial letter of each word followed by a flourish that looks somewhat like a cursive letter ' $\ell$ ', are transcribed as $\mathrm{f} \ell, \mathrm{g} \ell$, and $\mathrm{c} \ell$ respectively. 


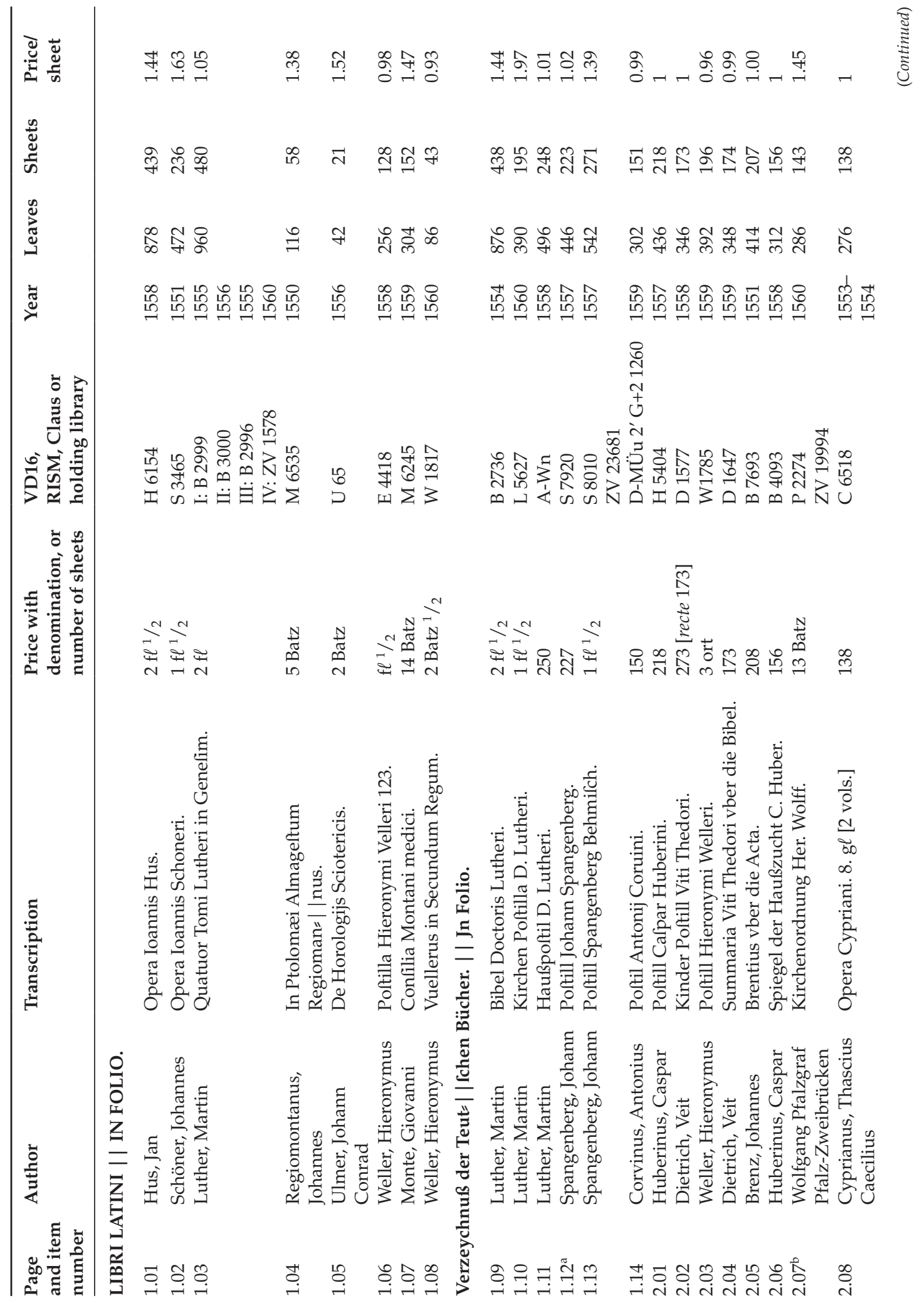




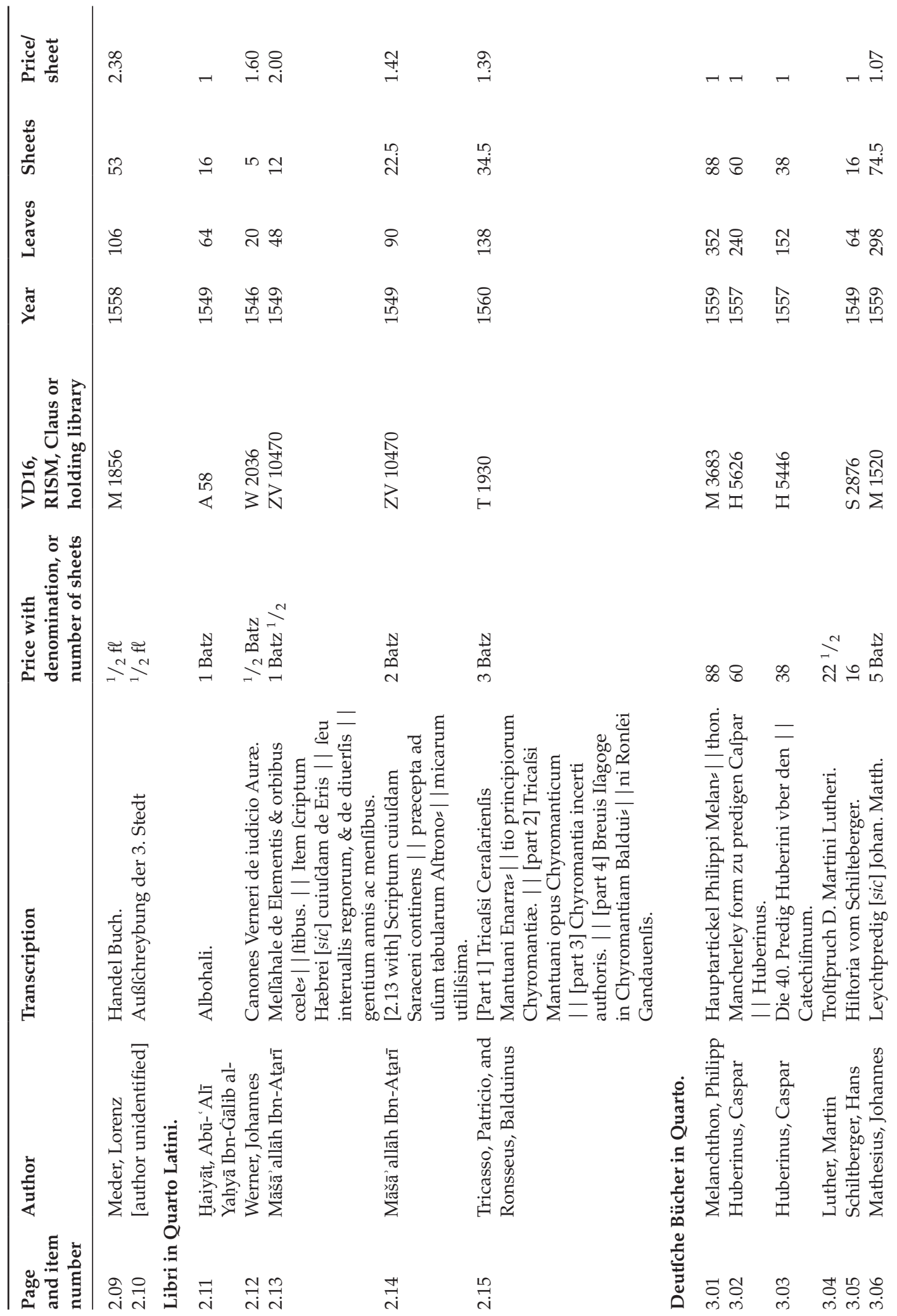




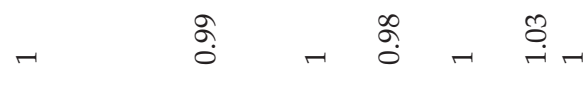

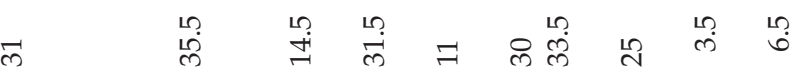

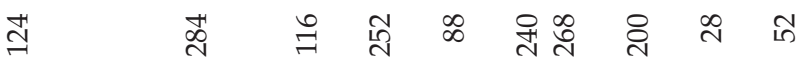

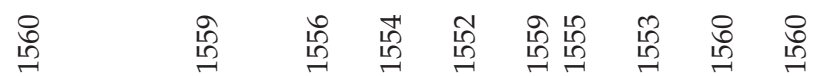

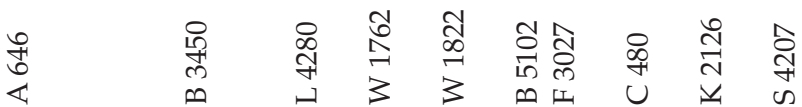

粂

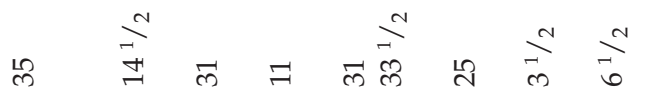

क्षे

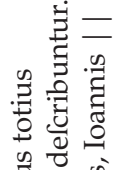

0
0
0

$\Xi \widetilde{g}$

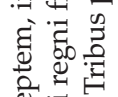

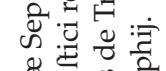

8 运它

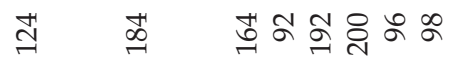

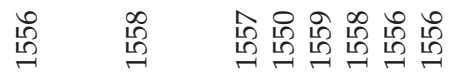

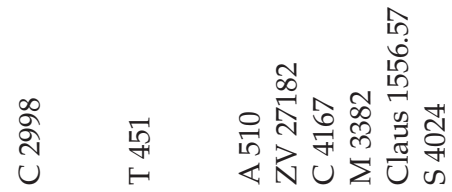

实

की

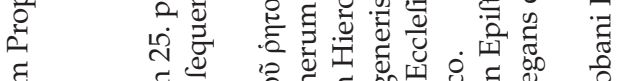

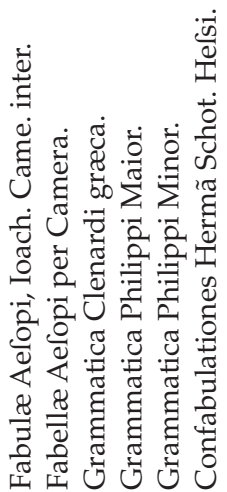

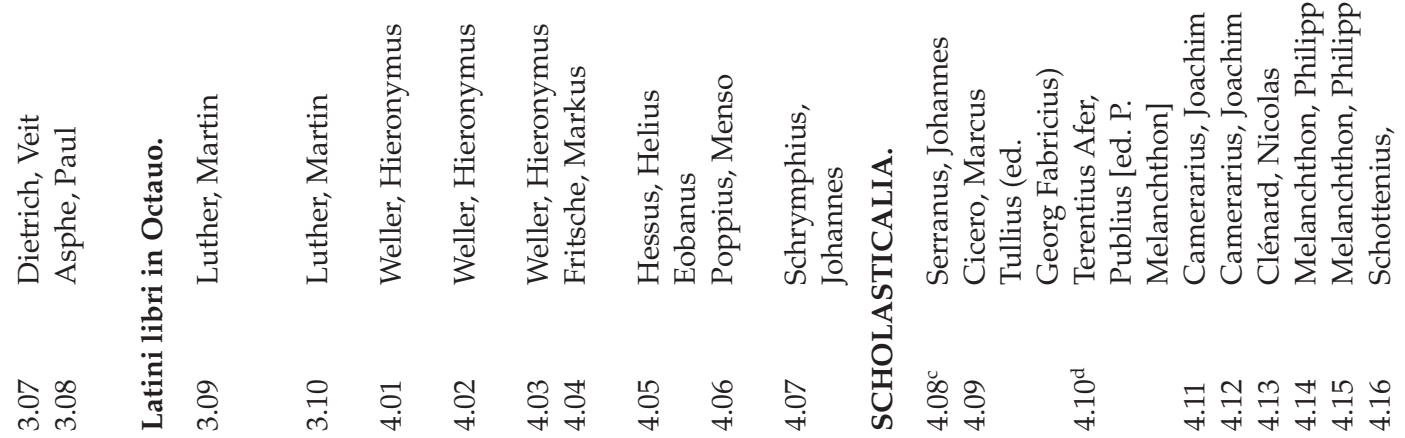




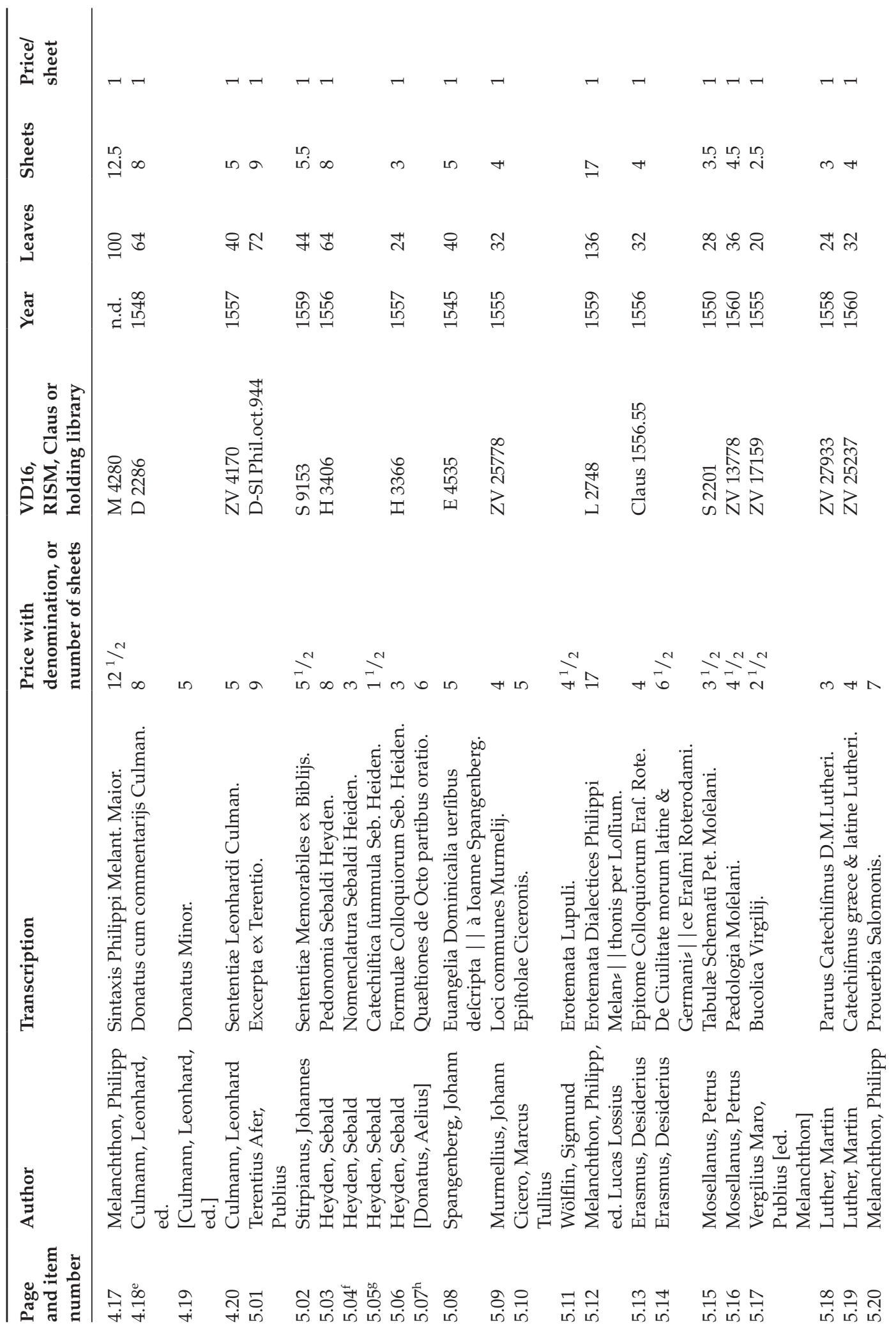


Lึ $\mathrm{L}$

ก) กิ่

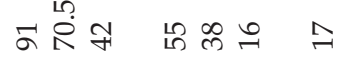

$\stackrel{2}{2}$

\&늠

와 ำ

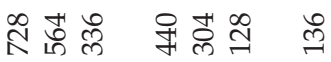

ชูก กิ

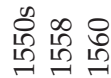

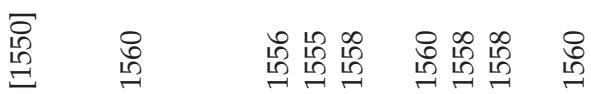

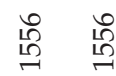

ते

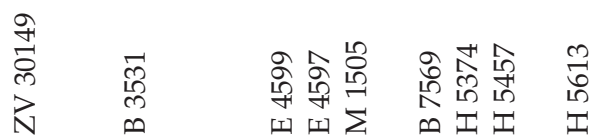

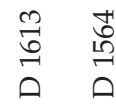

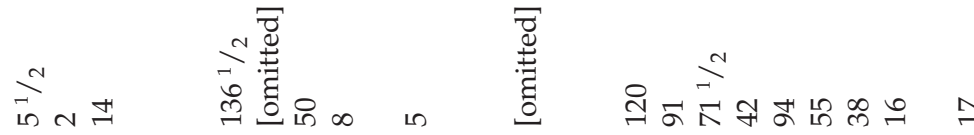

ำ 은

追

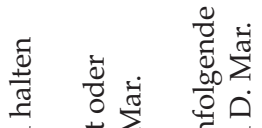

:

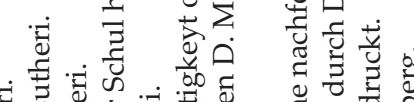

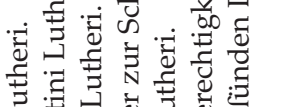

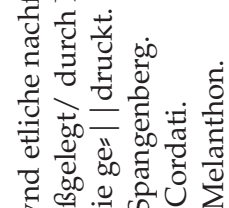

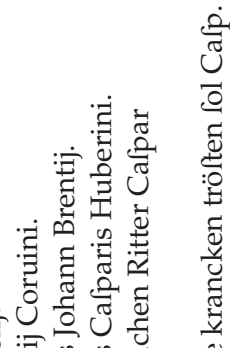

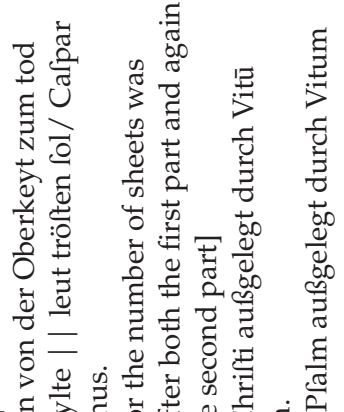

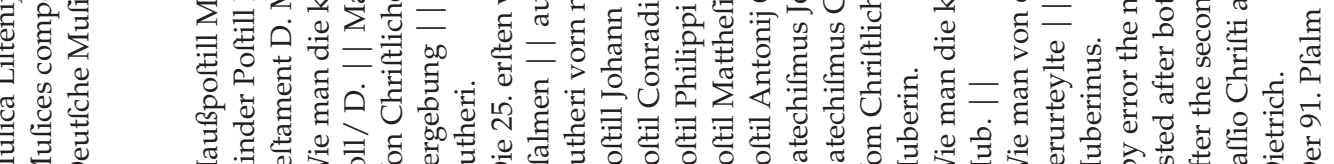

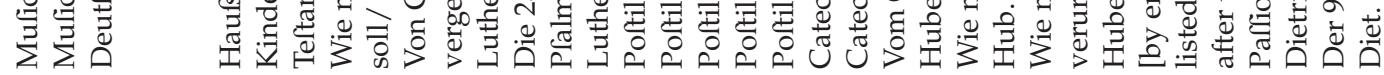

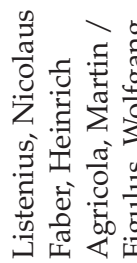

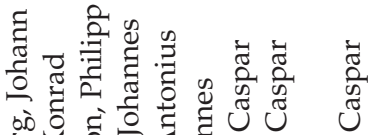

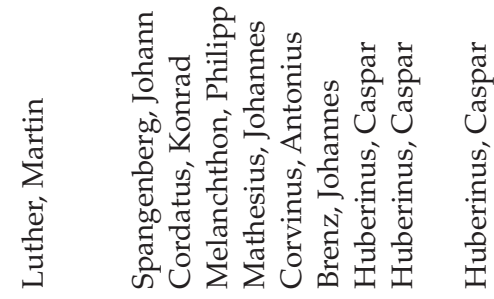

:

$\sum_{i=1}^{\pi} \sum_{i=1}^{\pi} \sum_{i=1}^{\pi}$

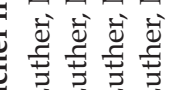

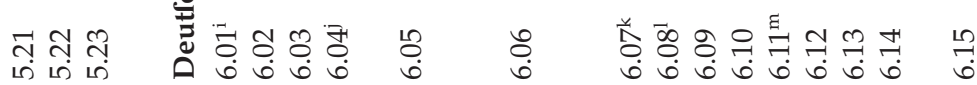

$\stackrel{0}{\overparen{6}} \frac{\pi}{6}$ 


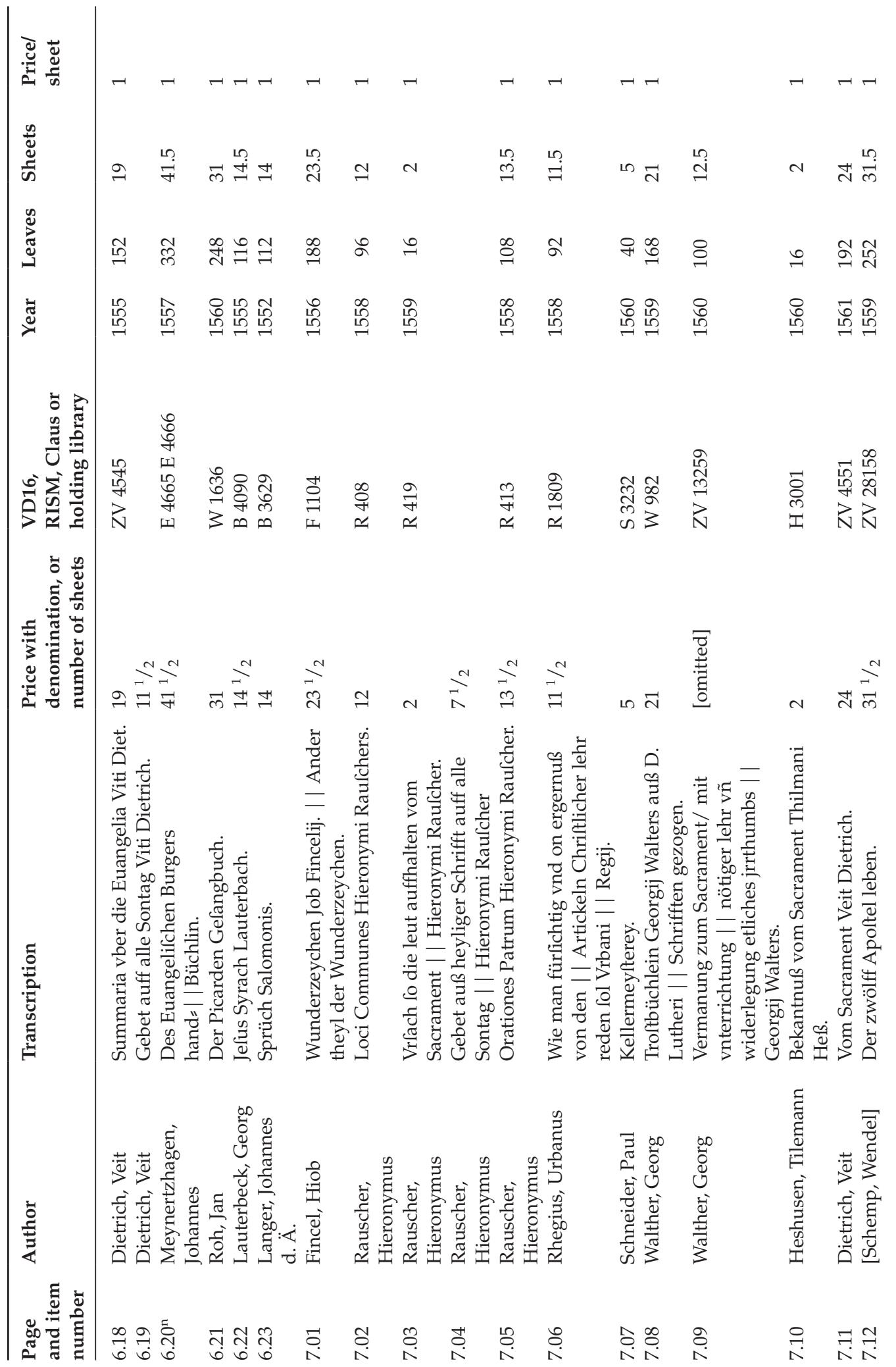




\begin{tabular}{|c|c|c|c|c|c|c|c|c|c|}
\hline- & $r-r$ & $\neg-r-\grave{0}$ & $\stackrel{8}{\stackrel{0}{\circ}}$ & - & - & - & - & $\neg-r-$ & $\neg-r-$ \\
\hline$\vec{N}$ & $\vec{\lambda} a$ & 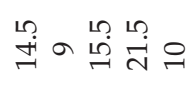 & 욱 & $\exists$ & $\vec{\sim}$ & $\exists$ & ㄴ & 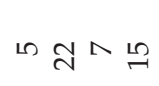 & 규 유 \\
\hline$\infty$ & 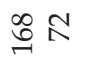 & $\underset{\exists}{\sim} \mathbb{N} \underset{\exists}{\mathbb{N}} \infty$ & $\infty$ & $\infty$ & กิ & $\stackrel{\text { लै }}{\sim}$ & ले & ○ ఫ্র & 出윰 \\
\hline 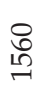 & 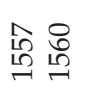 & 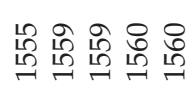 & 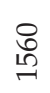 & 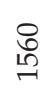 & 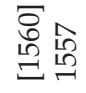 & $\begin{array}{l}\infty \\
\stackrel{\infty}{L} \\
\stackrel{1}{\sim}\end{array}$ & 高 & 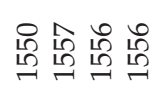 & 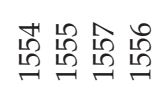 \\
\hline ८ & 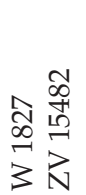 & 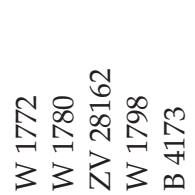 & \begin{tabular}{l}
$\infty$ \\
\multirow{1}{*}{} \\
ते \\
\multirow{N}{*}{}
\end{tabular} & $\begin{array}{l}8 \\
8 \\
\stackrel{0}{1} \\
\text { I }\end{array}$ & $\begin{array}{l}\mathbb{W} \\
\mathbb{\infty} \\
\mathbb{N} \\
\simeq\end{array}$ & 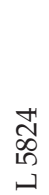 & $\begin{array}{l}\stackrel{8}{\circ} \\
\stackrel{1}{1} \\
0\end{array}$ & 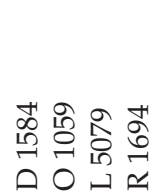 & 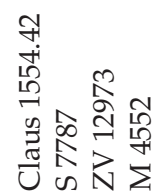 \\
\hline
\end{tabular}

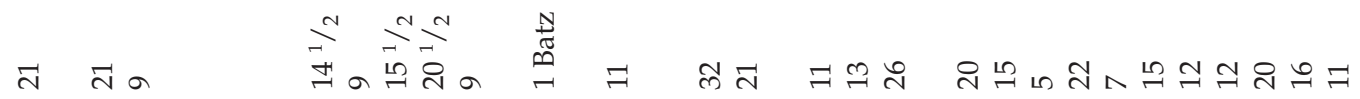

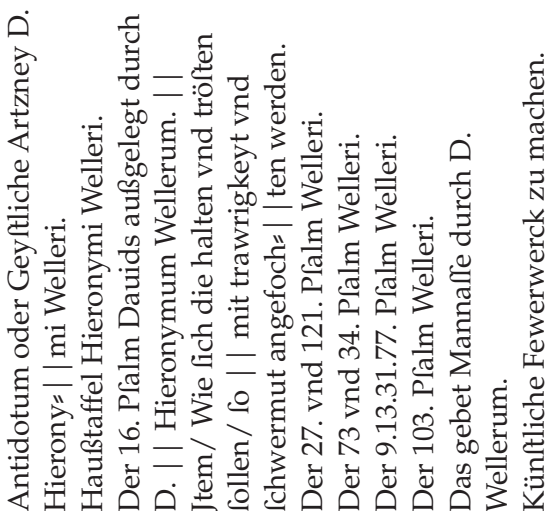
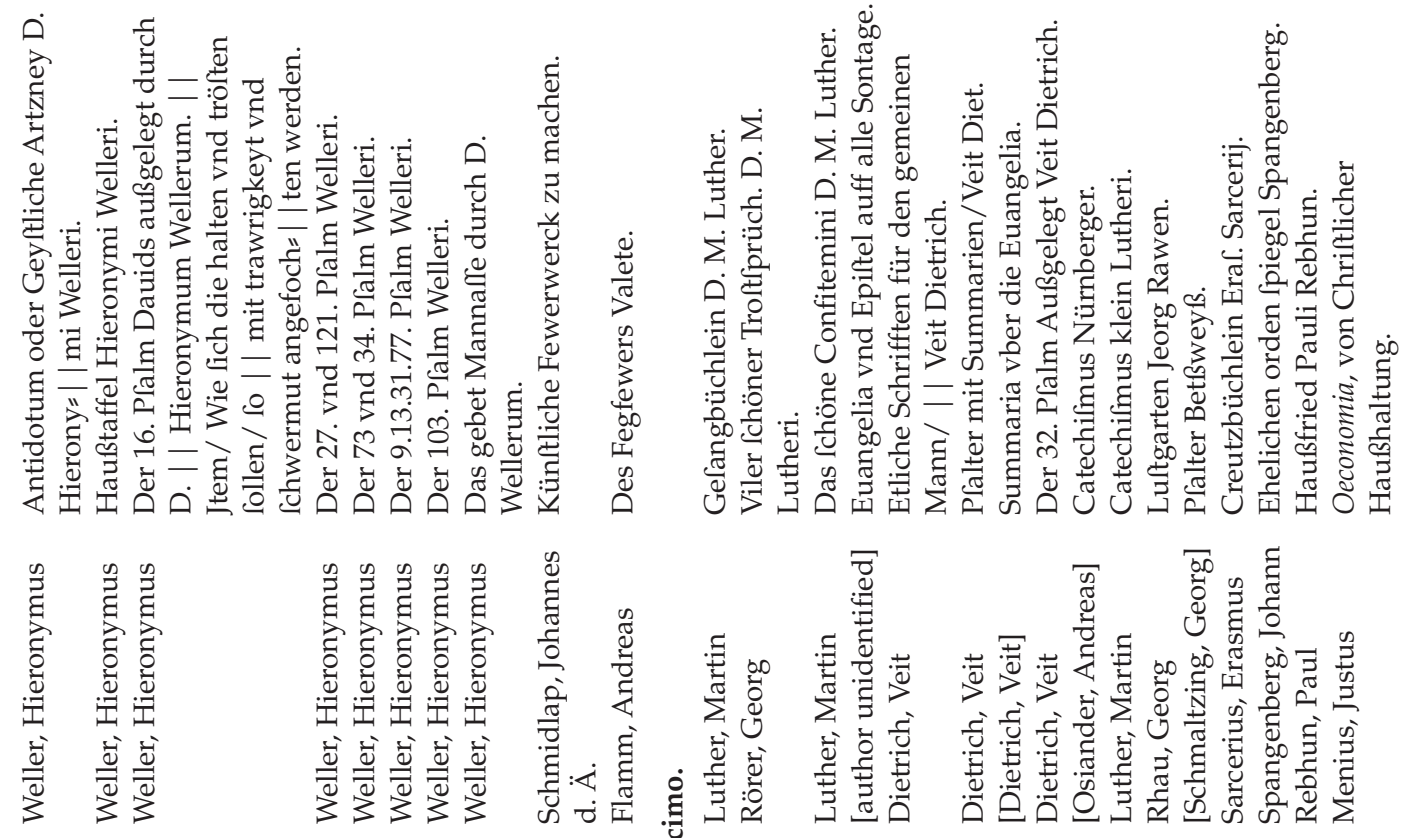

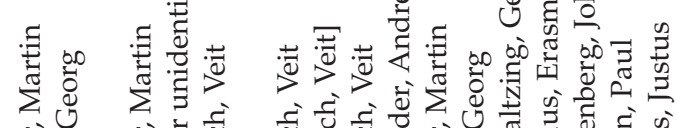

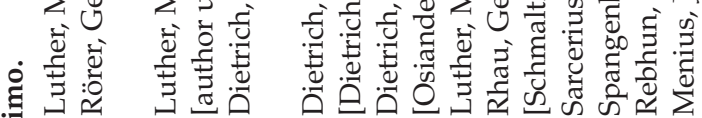

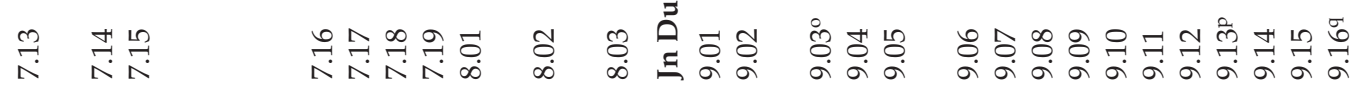




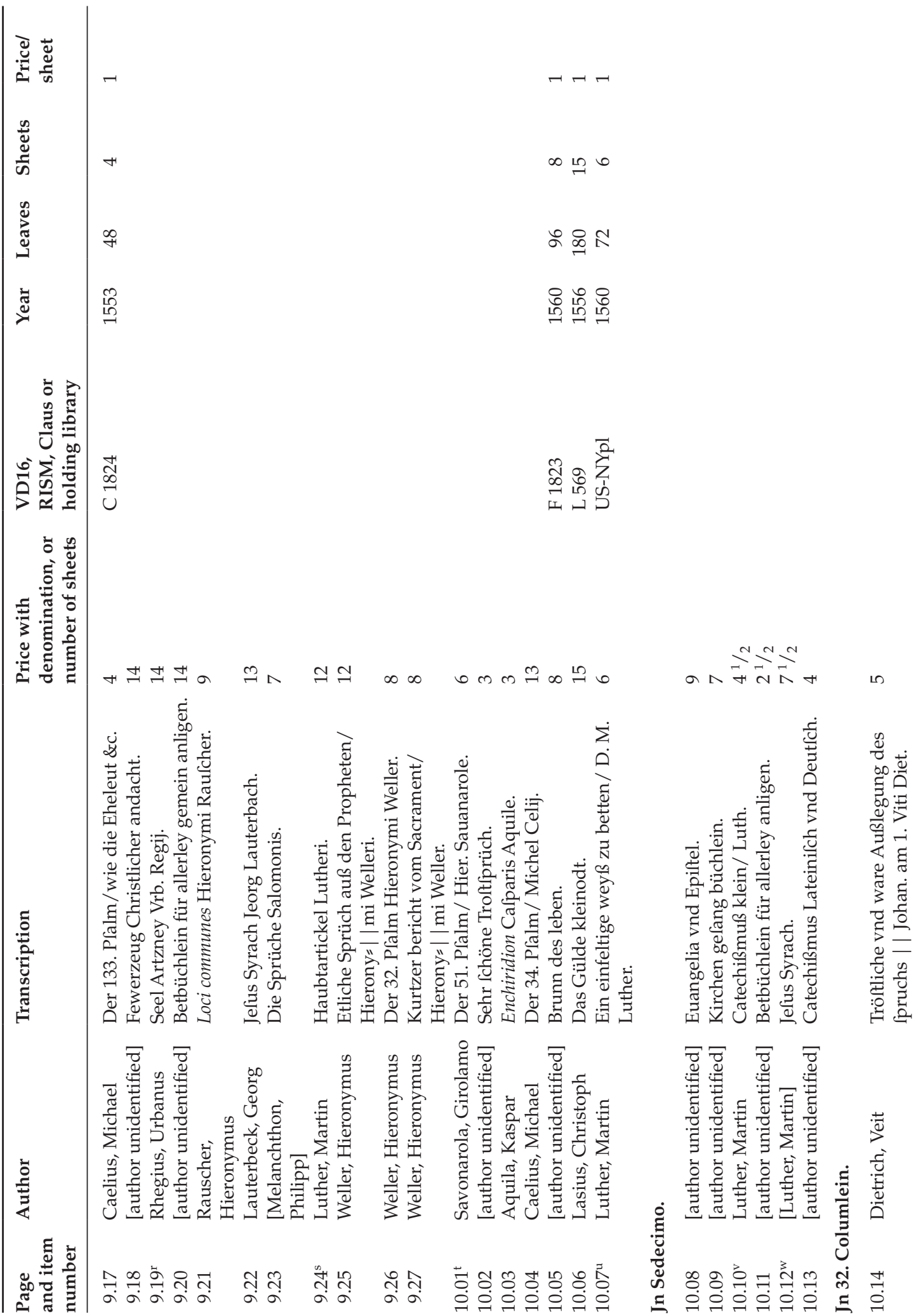




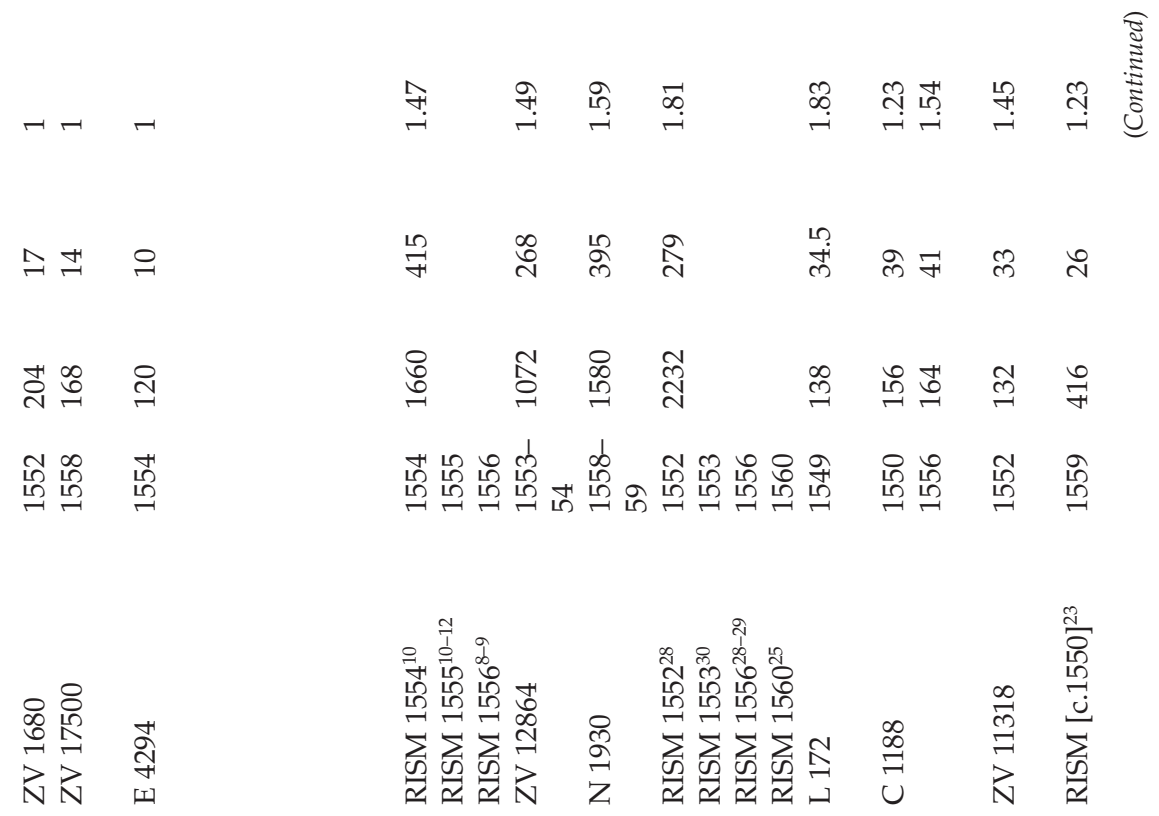

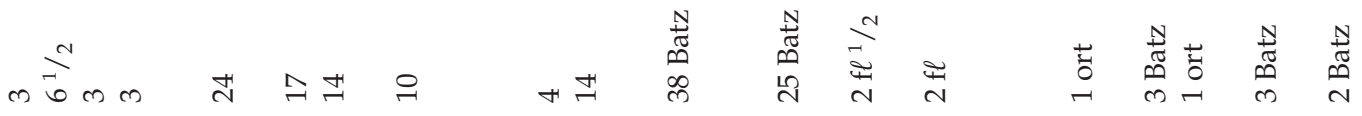

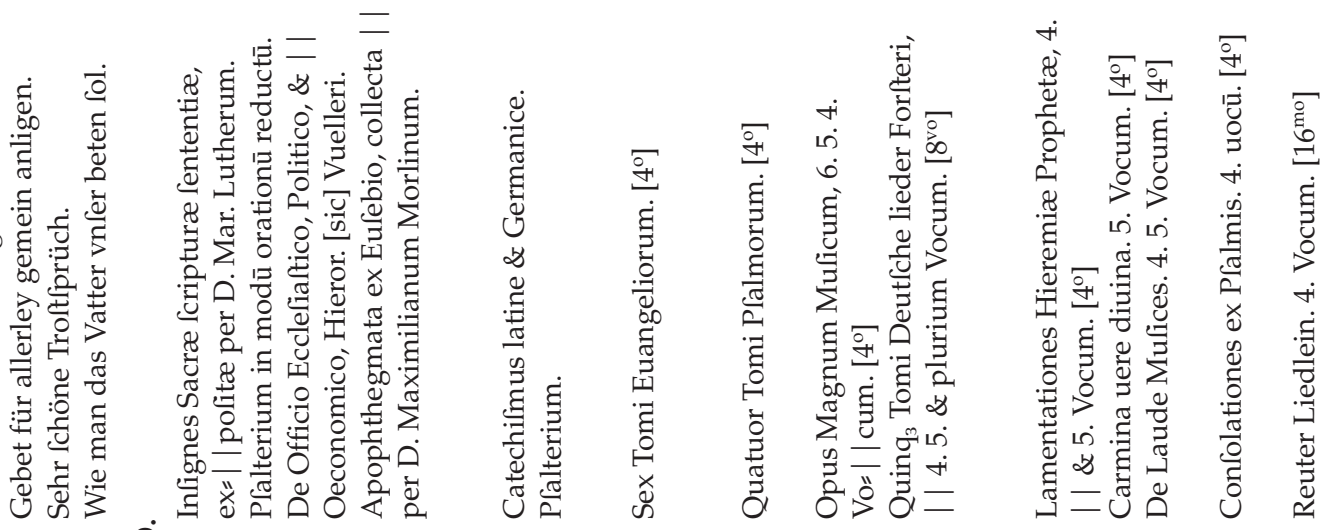

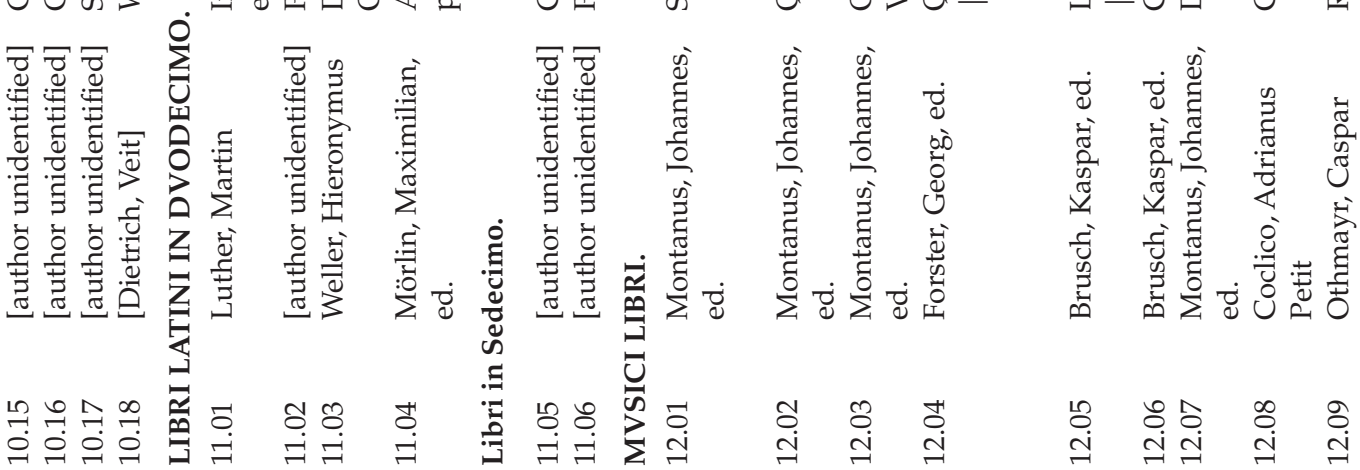




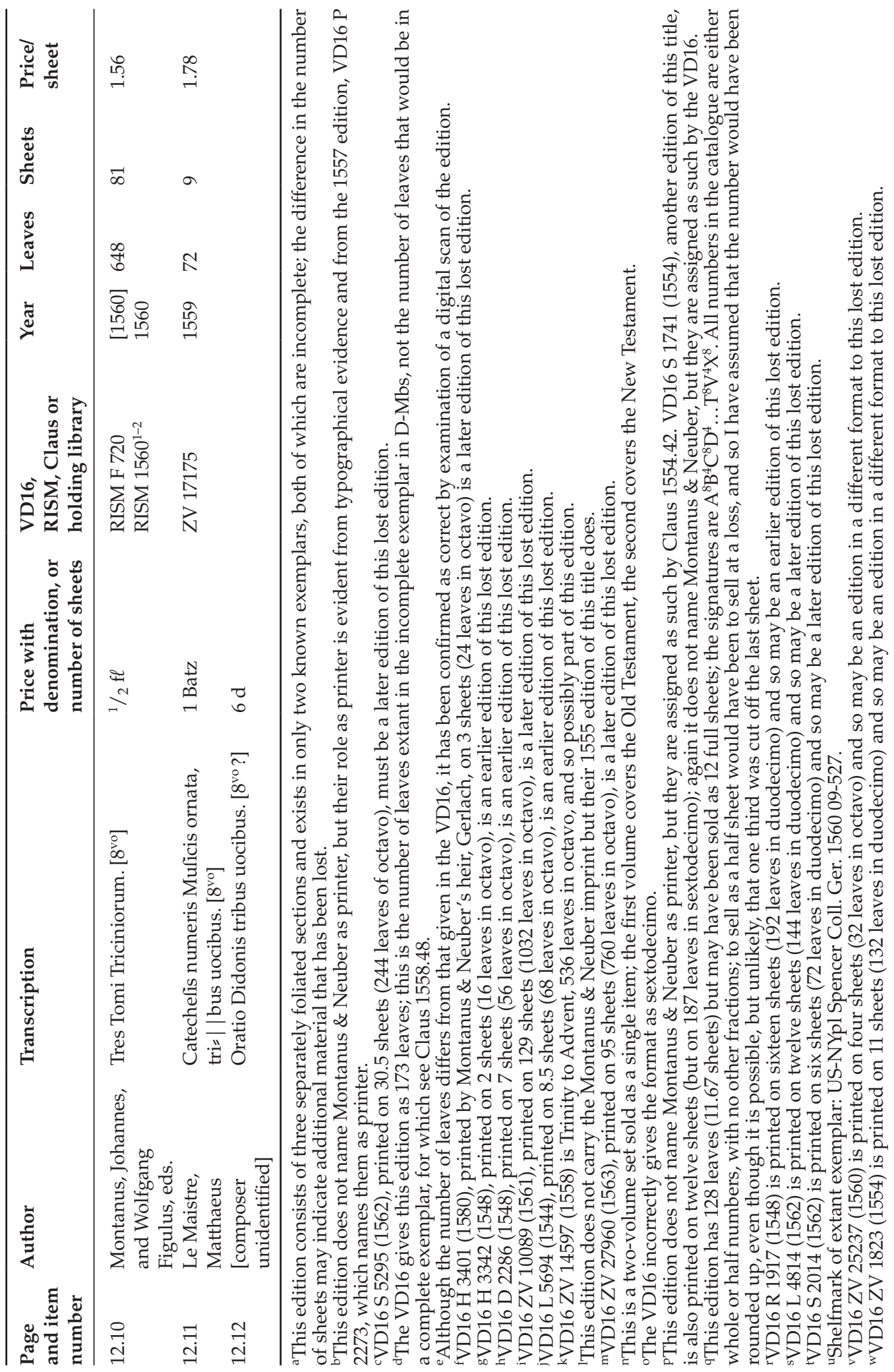




\section{Notes}

1 I am grateful to the staff of the Staatsbibliothek Bamberg for their assistance during my visit to examine the only known exemplar of this catalogue, to Grantley McDonald for comments on earlier drafts of this chapter, and to Bonnie Blackburn for comments on the music edition De laude musices and for sending me concordances that I had missed. This chapter is dedicated to Susan Jackson, whose ground-breaking research on Montanus \& Neuber has laid a foundation for all future research on this important music publishing house.

2 Göhler, Verzeichnis; Chapman, 'Printed Collections'; Bernstein, 'Bibliography'.

3 Coppens, 'A Census', 563.

4 Ameln, 'Ein Nürnberger Verlegerplakat'; Gustavson, 'The Music Editions of Christian Egenolff'.

5 Ernesti, who led the Endter printing house in Nuremberg from 1717 until his death in 1723, may have used the exemplar subsequently owned by Georg Andreas Will. (Kelchner, 'Endtner', 111.)

6 Ernesti, Die Wol-eingerichtete Buchdruckerë̈, fol. $\mathrm{f} 2^{\mathrm{v}}-\mathrm{f} 3^{\mathrm{r}}$.

7 For example, directly, such as Jackson, 'Berg and Neuber', 11-12 and Engelsing, 'Festpreise', 30 31; or indirectly through Kirchhoff, Geschichte, 24 and 32, such as Wohnhaas, 'Montanus', col. 488. As recently as 2015, Reske, Buchdrucker, 739, repeated that the catalogue was not extant.

8 Will, Bibliotheca Norica Williana, 8: 63, Nr. 308, under the heading '7. Res libraria. a. Typographia. [Unnumbered subsection] In Octavo'. He transcribes the entire title with minor typographical standardisation. Wagner, 'Nachträge', 131, cites Will's entry and notes that Will's exemplar was missing. Grimm, 'Buchführer', col. 1235, doesn't cite the source for his knowledge of the catalogue, but the only author in his bibliography who mentions it is Wagner.

9 I am grateful to Carolin Gillich, Stadtbibliothek Nürnberg, for this information (email of 24 April 2019).

10 Richter, ‘Bibliographische Beiträge', 217-218.

11 'Dieser Index ist als frühes Beispiel eines Katalogs mit Preisen und Umfangsangaben für das deutsche Sprachgebiet besonders bemerkenswert' (Richter, 'Bibliographische Beiträge', 218). In a later article, 'Humanistische Bücher', 200-201, Richter made additional comments on the rarity of sixteenth-century German catalogues giving either prices or number of sheets.

12 Jürgensen, Bibliotheca Norica, 1693.

13 Gustavson, 'Montanus \& Neuber', $M G G^{2}$; Gustavson, 'Montanus \& Neuber', MGG online.

14 Confirmed by chainlines and position of watermark, see STVC, http://manual.stcv.be/page/ List_of_Bibliographical_Formats.

15 See Piccard, Kronen-Wasserzeichen, Abteilung X (mit Kleeblattkreuz), most similar to watermark 2. The provenance of all Abteilung $X$ watermarks is Upper Rhine/Vosges. See also the type Wasserzeichen-Informationssystem: Symbole/Herrschaftszeichen - Krone - Bügel zweikonturig frei, ohne Beizeichen - Bügel mit Kleeblattkreuz - Bogen mit Perlen außen - Reif mit Perlen und Zacken (www.wasserzeichen-online.de).

16 Hirsch, Diptychorum, 206, 'Die Herren Diaconi bey St. Jacob', entry 9.

17 Ameln, 'Ein Nürnberger Verlegerplakat' and also a manuscript Gerlach catalogue in Vienna in the Haus-, Hof- und Staatsarchiv - Reichshofrat - Miscellanea - Bücherkommission im Reich, 1 (1557-1628), folder 57, fol. $42^{\mathrm{r}-\mathrm{v}}$. For examples of other printed catalogues see Richter, 'Die Sammlung' and Richter, Verlegerplakate.

18 Coppens, 'A Census', 562.

19 Catalogue numbers [4.08] (1562), [6.01] (1561; 129 sheets, not the expected 136.5, and so this is not the edition in the catalogue), [6.11] (1563), [7.11] (1561), [9.24] (1562) and [10.01] (1562).

20 Although this is pure speculation, there could have been a 1559 catalogue (published or not) that included books which were in preparation but which had not yet appeared; if so, there may have been slight differences between the expected number of sheets and the actual number of sheets, but with the expected number appearing in the 1560 catalogue.

21 Erasmus' De Ciuilitate [5.14] is priced at 6.5 sheets, but the Valentin Neuber edition (VD16 E 2267) is 6 sheets (48 leaves) of octavo; Luther's Testament [6.03] is priced at 50 sheets, but the Valentin Neuber edition (VD16 ZV 16378) is 52 sheets (416 leaves) of octavo; the Gesangbüchlein D. M. Luther [9.01] is priced at 32 sheets, but the Valentin Neuber edition (RISM $1562^{07}$ ) is 31 sheets $(371$ leaves) of duodecimo; the Kirchen gesang büchlein [10.09] is priced at 7 sheets, but the Valentin Neuber edition (VD16 K 935) is 7.5 sheets (120 leaves) of sextodecimo. Although Melanchthon's Die Sprïche Salomonis [9.23] is priced at 7 sheets and the Valentin Neuber edition (VD16 B 3604) is printed on 7 sheets, the Montanus \& Neuber edition is in duodecimo format whereas the Valentin 
Neuber edition is in octavo format. The only exception is Melanchthon's Prouerbia Salomonis [5.20], priced as 7 sheets; the Valentin Neuber edition (VD16 ZV 26825) consists of 7 sheets of octavo. This could be explained if one edition was a copy of the other, or if both were copies of an earlier edition by another printer.

22 An anomaly in the catalogue that I have not been able to resolve is item [2.08]: 'Opera Cypriani. 8. $\mathrm{g} \ell 138 \mathrm{cl}$ '. This is the only instance of an entry having what appears to be both a price in currency and a number of sheets. The extant Montanus \& Neuber edition of this item is printed on 138 sheets and so the reference to 138 sheets is correct. Jacob, Rechenbuch, fol. $148^{\mathrm{v}}$, gives 'gl.' as being an abbreviation for 'Groschen'; if the abbreviation here indicates 'Groschen' this would be the only reference to Groschen in the catalogue. One Groschen in Nuremberg at this time was worth 7 Pfennig (Köbel, Rechenbuch, fol. 15', 'Müntz zu Nürenberg': 'VII. Pfenning ein Grosch. XXXVI. Groschen ist ein Gulden.'), and so 8 Groschen was 56 Pfennig. A price of 0.4 Pfennig per sheet, against the demonstrated 1.5 Pfennig per sheet (almost four times the price) for premium editions does not seem feasible, and so the abbreviation presumably does not mean 'Groschen'. The book is in folio format and so the ' 8 ' cannot be related to format. An examination of this edition has not resulted in any further possibilities of that the ' 8 . g $\ell^{\prime}$ could mean.

23 Stifel, Rechenbuch, 24 (https:/ /www.e-rara.ch/zut/content/pageview/1257991).

24 Stifel, Rechenbuch, 46.

25 Pock, Rechenbüchlein, fol. D1v.

26 The number of sheets is followed by the abbreviation ' $\mathrm{c} \ell$ ', which Richter, 'Humanistische Bücher', 201, identifies as an abbreviation for 'chartae'. This abbreviation is also used for 'Zentner', a one-hundredth part (see Werner, Rechenbuch, fol. D2 ${ }^{\mathrm{v}}$ ) and 'Centner', a unit of weight of 100 pounds ('ein Centner, das sind 100. lb.' and the next page where the abbreviation is given; Henning, Gerechnet Rechenbüchlein, fol. $)\left([\mathrm{sic}] 5^{\mathrm{r}-\mathrm{v}}\right)$.

27 Richter, 'Humanistische Bücher', 201, based on his observation that the two ways of indicating the cost to purchaser changed back and forth throughout the catalogue, suggested that they are therefore interchangeable. However, he did not analyse the types of books assigned to each category; such an examination demonstrates that his conclusion is not substantiated.

28 Koppitz, Druckprivilegien, 40: Johann vom Berg Erben, Karton 6, Nr. 14 of 5 April 1566; 180: Dietrich Gerlach, Karton 23, Nr. 30 of 27 July 1568; 96: Alexander Dietrich, Karton 13, Nr. 29, undated, referring to Dietrich Gerlach's privilege for Mathesius' Postilla; 178: Valentin Geissler (who married Neuber's widow), Karton 23, Nr. 17, of 14 December 1575, about taking over Dietrich Gerlach and Alexander Dietrich's privilege for Mathesius; 271: Paul Kauffmann, Karton 35, Nr. 12, dated 15 April 1592, taking over the privilege of 27 July 1568 held by his ancestor ('Ahnherr') [no -n] Dietrich Gerlach. A few other editions or sets of editions that have privileges, but for which there are no Imperial records, are discussed in Jackson, 'Berg and Neuber', 73-74; for at least some of those the privilege was held by individuals other than Montanus \& Neuber.

29 The edition carries a five-year [Imperial] privilege. There is no record of who held the privilege. Montanus \& Neuber reprinted the book in 1561 (VD16 S 3121).

30 Vietor's 1679 book on layout is titled Neu-auffgesetztes Format-Büchlein: Worinnen Alle Figuren abgefasset || wie man die Columnen recht ordentlich außschiessen und stellen soll || so wohl in groß-als kleinen Formaten. Geßner's 1740 definition in his Buchdruckerkunst, 178, reads: 'Columnen, heisen [sic] die Seiten der Blätter; Nachdem nun ein Bogen in Octav, Quart, oder Folio gedruckt wird; So hat er viel, oder wenig, Columnen'.

31 I am grateful to Bonnie Blackburn for bringing to my attention Joachim Heller's two-voice setting of 'Divina res est Musica' as No. 98 of this anthology; this led to me noticing the printed texts at the end of this edition. Grantley McDonald has pointed out to me that 'Divina res est Musica' was 'one of many paratexts in the published version of a poem by Joannes Holtzheuser on the dignity and powers of music, recited during a lecture on music given at the University of Wittenberg by Heinrich Faber on 26 April 1551. Indeed, the theme of the 1556 publication, "On the praise of music", is precisely that of Holtzheuser's own work, which suggests a connection between the two publications. See Holtzheuser, Encomium Musicae, fol. A1 ${ }^{v}$. Further on this event, see Leaver, Luther's Liturgical Music, 84-85'. One of the unica in De laude musices is a setting of this text by Heinrich Faber.

32 Bonnie Blackburn has kindly pointed out to me that the text 'Laeta graves abigit' also appears in Rotenbucher's Diphona amoena (No. 4) as a contrafactum text for the Pleni of Brumel's Missa Je nay deul; this is the only setting of this text listed on RISM-online. 
33 Othmayr died in 1553, and so his motet is unlikely to have been specifically composed for this collection; Peschin disappears from the records in 1547, and so the same is presumably true for his setting.

34 According to the catalogue it is quarto, the same format given in VD16; RISM DKL gives the format as octavo. All sources indicate that this book has 388 or 390 leaves, but my examination of the exemplar in A-Wn gave 298 leaves (Part I: ${ }^{* 6} \mathrm{~A}-\mathrm{Z}^{4} \mathrm{Aa}^{4}=102$ leaves; Part II: $\mathrm{Bb}-\mathrm{Pp}{ }^{4}=56$ leaves; Part III Qq-Zz ${ }^{4}$ Aaa-Zzz ${ }^{4}$ Aaaa-Dddd ${ }^{4}=140$ leaves).

35 Serpilius, Georgii Serpilii, 69, No. CCX. Serpilius is cited by Wackernagel, Bibliographie, 307, No. 794, which is cited by RISM DKL.

36 Heyden's involvement is indicated only by the fact that the poem 'Ad lectorem' on $\mathrm{f}$. $\mathrm{A} 2^{\mathrm{r}}$ is signed 'S. H.'.

37 Stallybrass, 'Little Jobs', 322. I am grateful to Kate van Orden for bringing Stallybrass' chapter to my attention.

\section{References}

Ameln, Konrad. 'Ein Nürnberger Verlegerplakat aus dem 16. Jahrhundert'. In Musik und Verlag: Karl Vötterle zum 65. Geburtstag am 12. April 1968, edited by Richard Baum and Wolfgang Rehm. Kassel: Bärenreiter, 1968, 136-142.

Bernstein, Lawrence F. 'The Bibliography of Music in Conrad Gesner's Pandectae (1548)'. Acta musicologica 45 (1973): 119-163.

Chapman, Catherine W. 'Printed Collections of Polyphonic Music Owned by Ferdinand Columbus'. Journal of the American Musicological Society 21 (1968): 34-84.

Charteris, Richard. Johann Georg von Werdenstein (1542-1608): A Major Collector of Early Music Prints. Detroit Studies in Music Bibliography 87. Sterling Heights, MI: Harmonie Park Press, 2006.

Claus, Helmut. Melanchthon-Bibliographie 1510-1560. 4 vols. Quellen und Forschungen zur Reformationsgeschichte 87. Gütersloh: Gütersloher Verlagshaus, 2014.

Coppens, Christian. 'A Census of Publishers' and Booksellers' Catalogues up to 1600: Some Provisional Conclusions'. The Papers of the Bibliographical Society of America 102 (2008): 557-565.

Engelsing, Rolf. 'Festpreise im europäischen Buchhandel des 15., 16. und 17. Jahrhunderts: Ursprünge eines preispolitischen Konzepts'. Schmollers Jahrbuch für Wirtschafts- und Sozialwissenschaften 91.1 (1971): 21-35.

Ernesti, Johann Heinrich G. Die Wol-eingerichtete Buchdruckerë̈ ... nebst einer summarischen Nachricht von den Buchdruckern in Nürnberg. Nuremberg: Heirs of Johann Andreas Endter, 1733.

Geßner, Christian F. Die so nöthig als nützliche Buchdruckerkunst und Schriftgießerey. Leipzig: Geßner, 1740. VD18 12440469-001.

Göhler, Albert. Verzeichnis der in den Frankfurter und Leipziger Messkatalogen der Jahre 1564 bis 1759 angezeigten Musikalien. Leipzig: C. F. Kahnt Nachfolger, 1902. Reprint Hilversum: Knuf, 1965.

Grimm, Heinrich. 'Die Buchführer des deutschen Kulturbereichs und ihre Niederlassungsorte in der Zeitspanne 1490 bis um 1550'. Archiv für Geschichte des Buchwesens 7 (1967): cols. 1153-1772.

Gustavson, Royston. 'Montanus \& Neuber'. In MGG². Personenteil, vol. 12. Kassel: Bärenreiter, 2004, cols. 371-373.

Gustavson, Royston. 'Montanus \& Neuber'. In MGG Online (2018). https:/ /www.mgg-online.com/ $\mathrm{mgg} / \mathrm{stable} / 47440$.

Gustavson, Royston. 'The Music Editions of Christian Egenolff: A New Catalogue and Its Implications'. In Early Music Printing in German-Speaking Lands, edited by Andrea Lindmayr-Brandl, Elisabeth Giselbrecht and Grantley McDonald. London and New York: Routledge, 2018, 153-195. 
Heidrich, Jürgen. 'Musik und Humanismus an der Fürstenschule St. Afra zu Meissen im 16. Jahrhundert'. In Musikalische Quellen — Quellen zur Musikgeschichte: Festschrift für Martin Staehelin zum 65. Geburtstag, edited by Ulrich Konrad with Jürgen Heidrich and Joachim Marx. Göttingen: Vandenhoeck \& Ruprecht, 2002, 97-109.

Henning, Nikolaus. Gerechnet Rechenbüchlein || Von aller handt | | fürnembsten Gewerben vnd || Kauffmañs Waren/so mit dem stück/ || Centner/Techer/Dutzet/Schock/Zimmer/ || Auch im Silberkauff/ den Marcken/Loten vnd Quinten | nach/verhandelt werden.... | | Frankfurt am Main: Weigand Han Erb[en], Sigmvnd Feierabent, and Georg Rab, 1565. VD16 H 1935.

Hirsch, Carl C. Diptychorum ecclesiarum Norimbergensium succincta enucleatio. Nuremberg: Roth, 1766.

Holtzheuser, Johannes. Encomium Musicae, artis antiquiss[imae] || et divinae carmine elegiaco || scriptum, et recitatum in celeberri $=1$ | ma Academia VVitteber $=1$ |gensi, in praelectione Musicae Hen $=1$ | rici Fabri. Anno, 1551. 26. April. | |. Erfurt: Merten von Dolgen, 1551. VD16 H 4506.

Jackson, Susan. 'Berg and Neuber: Music Printers in Sixteenth-Century Nuremberg.' 2 vols. PhD dissertation, The City University of New York Graduate School, 1998.

Jacob, Simon. Ein New vnd Wol=| | gegründt Rechenbuch/auff den Linien ṽ̃ Ziffern/ | | sampt der Welschen Practic vnd allerley vortheilen/... || . Frankfurt am Main: Georg Rab for Sigmund Feyerabend and Simon Hüter, 1565. VD16 J 29.

Jürgensen, Renate. Bibliotheca Norica: Patrizier und Gelehrtenbibliotheken in Nürnberg zwischen Mittelalter und Aufklärung. Beiträge zum Buch- und Bibliothekswesen 43. Wiesbaden: Harrassowitz, 2002.

Kelchner, Ernst. 'Endtner: eine nürnbergische Buchhändler- und Buchdruckerfamilie'. In Allgemeine deutsche Biographie. Vol. 6. Leipzig: Duncker \& Humblot, 1877, 110-111.

Kirchhoff, Albrecht. Versuch einer Geschichte des deutschen Buchhandels im XVII. und XVIII. Jahrhundert. Leipzig: Hinrichsen, 1853.

Köbel, Jacob. Rechenbůch/ Auff Lini=| | en vnd Ziffern. Frankfurt a.M.: Egenolff, 1549. VD16 K 1664.

Koppitz, Hans-Joachim. Die kaiserlichen Druckprivilegien im Haus-, Hof- und Staatsarchiv Wien: Verzeichnis der Akten vom Anfang des 16. Jahrhunderts bis zum Ende des Deutschen Reichs (1806). Buchwissenschaftliche Beiträge aus dem deutschen Bucharchiv München 75. Wiesbaden: Harrassowitz, 2008.

Leaver, Robin. Luther's Liturgical Music: Principles and Implications. Grand Rapids, MI: Eerdmans, 2007.

Piccard, Gerhard. Die Kronen-Wasserzeichen. Die Wasserzeichenkartei Piccard im Hauptstaatsarchiv Stuttgart 1. Stuttgart: Kohlhammer, 1961.

Pock, Hans. Ein new Rechenbüch | | lein auff der Linien vĩ Federn/ mit vil schönē || Exempel/ auff allen kauffmanschlag/zå gewin ṽ̃ || verlust/mit sunderlichen vorteiln der Regel [...]. Nuremberg: Valentin Neuber, 1549. VD16 ZV 2143.

Reske, Christoph. Die Buchdrucker des 16. und 17. Jahrhunderts im deutschen Sprachgebiet, auf der Grundlage des gleichnamigen Werkes von Josef Benzing. Second edition. Beiträge zum Buch- und Bibliothekswesen 51. Wiesbaden: Harrassowitz, 2015.

Richter, Günter. 'Bibliographische Beiträge zur Geschichte buchhändlerischer Kataloge im 16. und 17. Jahrhundert'. In Beiträge zur Geschichte des Buches und seiner Funktion in der Gesellschaft: Festschrift für Hans Widmann zum 65. Geburtstag am 28. März 1973, edited by Alfred Swierk. Stuttgart: Hiersemann, 1974, 183-229.

Richter, Günter. 'Die Sammlung von Drucker-, Verleger- und Buchführerkatalogen in den Akten der kaiserlichen Bücherkommission'. In Festschrift für Josef Benzing zum sechzigsten Geburtstag 4. Februar 1964, edited by Elisabeth Geck and Guido Pressler. Wiesbaden: Pressler, 1964, 317-372.

Richter, Günter. 'Humanistische Bücher in Buchhändlerkatalogen des 15. und 16. Jahrhunderts'. In Das Verhältnis der Humanisten zum Buch, edited by Fritz Krafft and Dieter Wuttke. Kommission für Humanismusforschung Mitteilung IV. Boppard: Harald Boldt, 1977, 184-206. 
Richter, Günter. Verlegerplakate des XVI. und XVII. Jahrhunderts bis zum Beginn des Dreissigjährigen Krieges. Wiesbaden: Pressler, 1965.

Serpilius, Georg. Georgii Serpilii, Evangel. Predigers in Regenspurg, Fortsetzung der Zufälligen LiederGedancken. Regensburg: Seidel, [preface dated] 1704.

Stallybrass, Peter. "'Little Jobs": Broadsides and the Printing Revolution'. In Agent of Change: Print Culture Studies after Elizabeth L. Eisenstein, edited by Sabrina Alcorn Baron, Eric N. Lindquist, and Eleanor F. Shevlin. Amherst and Boston: University of Massachusetts Press, 2007, 315-341.

Stifel, Michael. Rechenbuch, || von der Welschen wnd Deu=||tschen Practick/ auff allerley vorteyl vnd be $=\mid$ |hendigkeit/mit erklerung viler Exempeln/ auff || mancherley art vnd weiß/nach der || kürtz vnd vorteyl/zu || machen. || Nuremberg: Petreius, 1546. VD16 S 9013.

Vietor, Johann Ludwig. Neu-auffgesetztes Format-Büchlein: Worinnen Alle Figuren abgefasset || wie man die Columnen recht ordentlich außschiessen und stellen soll || so wohl in groß-als kleinen Formaten .... Frankfurt a.M.: Drullmann, 1679. VD17 23:725616L.

Wackernagel, Philipp. Bibliographie zur Geschichte des deutschen Kirchenliedes im XVI. Jahrhundert. Frankfurt am Main: Heyder \& Zimmer, 1855.

Wagner, Rudolf. 'Nachträge zur Geschichte der Nürnberger Musikdrucker im sechzehnten Jahrhundert'. Mitteilungen des Vereins für Geschichte der Stadt Nürnberg 30 (1931): 107-151.

Werner, Nicolaus. Rechenbuch || Von der welschen prac=| | tick auff allerley Kauffmans hendel/ ond || sonderlich souiel der Nürnbergischen Lands art/ wnd || gebrauch belangt/ mit sonderm vorteyl/ ond be $=$ | hendigkeit auff mancherley art practicè || Durch || Nicolaum Werner || Rechenmeyster/ ond Burger zu || Nürnberg ... | |. Nuremberg: Montanus \& Neuber, 1561. VD16 W 2088.

Will, Georg Andreas. Bibliotheca Norica Williana. Vol. 8. Altdorf and Nuremberg: MonathKußlerischen Buchhandlung, 1793.

Wohnhaas, Theodor. 'Montanus'. In MGG'1. Vol. 9. Kassel: Bärenreiter, 1961, cols. 486-489. 